\title{
The oldest titanosaurian sauropod of the Northern Hemisphere
}

\author{
Alexander Averianov ${ }^{1,2,3}$ and Vladimir Efimov ${ }^{4}$ \\ 1Zoological Institute, Russian Academy of Sciences, Universitetskaya nab., 1, \\ St. Petersburg, 199034, Russian Federation; \\ 2Department of Sedimentary Geology, Institute of Earth Sciences, Saint Petersburg \\ State University, 16th Liniya V. O., 29, St. Petersburg, 199178, Russian Federation \\ ${ }^{3}$ Borissiak Paleontological Institute, Russian Academy of Sciences, Profsoyuznaya ul., 123, \\ Moscow, 117997, Russian Federation \\ ${ }^{4}$ Undory Paleontological Museum, Shkolnaya ul., 5, Undory, 433312, Russian Federation; \\ upm2002@mail.ru
}

Address correspondence and requests for materials to Alexander Averianov, lepus@zin.ru, dzharakuduk@mail.ru

\begin{abstract}
Volgatitan simbirskiensis, gen. et sp. nov., is described based on a series of anterior and middle caudal vertebrae from a single individual discovered in the Lower Cretaceous (upper Hauterivian, Speetoniceras versicolor ammonite Zone) marine deposits at Slantsevy Rudnik vertebrate locality near Ulyanovsk City, Russia. The new taxon is characterized by strongly procoelous anterior and middle caudal vertebrae, a long centrum of the first caudal vertebra, a strong ventral ridge in the anterior and middle caudal vertebrae, a neural arch positioned at the anterior half of the centrum, hyposphene-hypantrum articulation in the anterior caudal vertebrae, and somphospondylous bone texture. Phylogenetic analysis places the new taxon as a lithostrotian titanosaur, a basal member of the lineage leading to the Lognkosauria. This lineage previously contained only South American taxa with body mass reaching 60-70 tons. Volgatitan gen. nov. is the first European and the geologically oldest representative of this lineage. Its body mass is estimated as 17.3 tons. Discovery of Volgatitan gen. nov. suggests that the lithostrotian lineage leading to the Lognkosauria had a wider distribution in the Early Cretaceous and became extinct everywhere except South America by the end of the Early Cretaceous.
\end{abstract}

Keywords: Dinosauria, Sauropoda, Titanosauriformes, Titanosauria, Lithostrotia, Early Cretaceous, Eastern Europe, Russia.

Citation: Citation: Averianov, A and Efimov, V. 2018. The oldest titanosaurian sauropod of the Northern Hemisphere. Bio. Comm. 63(3): 145-162. https://doi. org/10.21638/spbu03.2018.301

Author's information: Alexander Averianov, Dr. Sci., Professor, orcid. org/0000-0001-5948-0799; Vladimir Efimov, Ph.D., Director

Manuscript Editor: Nikita Zelenkov, Borissiak Paleontological Institute Russian Academy of Sciences, Russia

Received: July 21, 2018;

Revised: September 15, 2018;

Accepted: September 18, 2018;

Copyright: (c) 2018 Averianov and Efimov. This is an open-access article distributed under the terms of the License Agreement with Saint Petersburg State University, which permits to the authors unrestricted distribution, and self-archiving free of charge.

Funding: The laboratory research by $A A$ received support from the Russian Scientific Fund (14-14-00015).

urn:Isid:zoobank.org:pub:47F64D6A-520F-4C07-BF47-6AF5BE4B654D

\section{Introduction}

The Cretaceous dinosaurs of European Russia are virtually unknown because most of this territory was covered by epicontinental seas during the whole Cretaceous Period (Moskvin, 1986). The rare dinosaur bones are found in near-shore marine sediments. These findings include an ornithopod tooth and vertebra from the Albian-Cenomanian of Belgorod Province, a poorly preserved theropod tooth and ankylosaur braincase fragment from the Maastrichtian of Volgograd Province, and a partial skeleton of ornithopod Riabininohadros weberae from the Maastrichtian of Crimea (Riabinin, 1945; Nesov, 1995; Arkhangelsky and Averianov, 2003; Averianov and Yarkov, 2004).

Another significant discovery of Cretaceous dinosaurs in European Russia was made by one of us (VE) in 1982 during prospecting for vertebrate fossils along the right bank of the Volga River, $0.5 \mathrm{~km}$ south of Slantsevy Rudnik settlement, about $5 \mathrm{~km}$ north of Ulyanovsk City, Russia. We discovered large bones embedded in two pyritic limestone nodules. In 1984-1987 three more limestone 
modules with bones were found at the same places. The concretions were subsequently washed out from the outcrop by the river. The extraction of the bones from the nodules took several years. Altogether seven fragmentary vertebrae were extracted. The first three recovered vertebrae were referred to as "gigantic vertebrae" of unknown taxonomic attribution (Efimov, 1987). In the early 1990s VE discussed these vertebrae with L. A. Nesov from Saint Petersburg State University, who suggested that they could be anterior caudals of a sauropod dinosaur. Subsequently, five vertebrae were briefly described and one (UPM 976/2) was figured in a short note (Efimov, 1997b). These materials were tentatively attributed to the Brachiosauridae in that publication. Later, the taxonomic attribution of these specimens was changed to the Titanosauridae (Efimov, 2001; Efimov and Efimov, 2015), although they were still referred to the Brachiosauridae in a recent publication (Efimov, 2016). In the later publication a photograph of six vertebrae was published (Efimov, 2016: Fig. 1). Alifanov (2012) noted that these procoelous caudal vertebrae are better referable to the Titanosauridae than to the Brachiosauridae.

The vertebrae represent successive anterior (including the first caudal) and middle caudals undoubtedly belonging to a single individual. The animal was buried in deep water marine deposits together with marine invertebrates and marine reptiles. The only other reliable Early Cretaceous records of dinosaurs in the region are fragmentary sauropod metacarpals found in the upper Hauterivian deposits $0.3 \mathrm{~km}$ north of Slantsevy Rudnik settlement (Efimov, 2001, 2016). In this paper we provide a detailed description of the sauropod caudal vertebrae from Slantsevy Rudnik.

The nomenclature of the vertebral fossae and laminae follows Wilson $(1999,2012)$ and Wilson et al. (2011). The described specimens are housed in Ulyanovsk Paleontological Museum (UPM).

\section{Geological context}

The sauropod caudal vertebrae described herein were found along the right bank of the Volga River, $500 \mathrm{~m}$ south of Slantsevy Rudnik Village (previously known as Zakharievskii Rudnik) in Ulyanovsk Province, Russia (Fig. 1). The marine Lower Cretaceous section, containing a rich invertebrate fauna, has been described repeatedly in the literature (Pavlow and Lamplugh, 1892; Pavlow, 1901; Chernova, 1951; Sazonova, 1958; Glazunova, 1967, 1973; Myatlyuk, 1984; Baraboshkin et al., 2001; Guzhikov, Baraboshkin, and Birbina, 2003; Blagovetshenskiy and Shumilkin, 2006a, b; Baraboshkin and Blagovetshenskiy, 2010). The section at Slantsevy Rudnik represents the upper part of the Hauterivian with a total thickness of $38.8 \mathrm{~m}$ (Baraboshkin and Blagovetshenskiy, 2010). The deposits consist of a monotonous thickness of dark gray, slightly sandy shales, interbedded with siltite beds and containing large carbonate concretions (Fig. 1). These deposits are referred to the ammonite Speetoniceras versicolor Zone, the lower of the three ammonite zones of the upper Hauterivian (Pavlow, 1901; Glazunova, 1967; Baraboshkin and Blagovetshenskiy, 2010). UPM 976 was found in the dark gray shales and siltites of the g-3.1 horizon, in the lower part of the Speetoniceras versicolor Zone (Fig. 1). Besides the abundant invertebrates, the Hauterivian outcrops near Slantsevy Rudnik produced remains of marine reptiles, including the ichthyosaur Plutoniosaurus bedengensis and pliosaurids Makhaira rossica and Luskhan itilensis (Efimov, 1997a; Fischer et al., 2015, 2017).

\section{Systematic paleontology}

Dinosauria Owen, 1842

Saurischia Seeley, 1887

Sauropoda Marsh, 1878

Titanosauriformes Salgado et al., 1997

Titanosauria Bonaparte et Coria, 1993

Lithostrotia Upchurch et al., 2004

Volgatitan gen. nov.

urn:lsid:zoobank.org:act:6DF2AAE2-E560-4AA6-

B38C-1B2A7314BC85

Etymology - From Volga River and Greek Titáv (titan), a member of the second order of divine beings, descended from the primordial deities and preceding the Olympian deities in Greek mythology.

Type species - Volgatitan simbirskiensis n. sp.

Differential diagnosis - As for the type and only species.

Distribution - Early Cretaceous, Eastern Europe.

Volgatitan simbirskiensis sp. nov.

urn:lsid:zoobank.org:act:91E2FF16-66DB-4CDD-

B8DA-63414DFF30E9

Figs $2-5$

Etymology - From Simbirsk, the former name of Ulyanovsk city.

Holotype - UPM 976/1-7, seven caudal vertebrae from a single individual.

Type horizon and locality - Slantsevy Rudnik, near Ulyanovsk city, Ulyanovsk Province, Russia; Lower Cretaceous (upper Hauterivian, Speetoniceras versicolor ammonite Zone).

Diagnosis - Referred to Titanosauriformes based on the neural arch of anterior and middle caudal vertebrae positioned at the anterior half of the centrum. Referred to Titanosauria based on the procoelous anterior and middle caudal vertebrae with strongly convex 


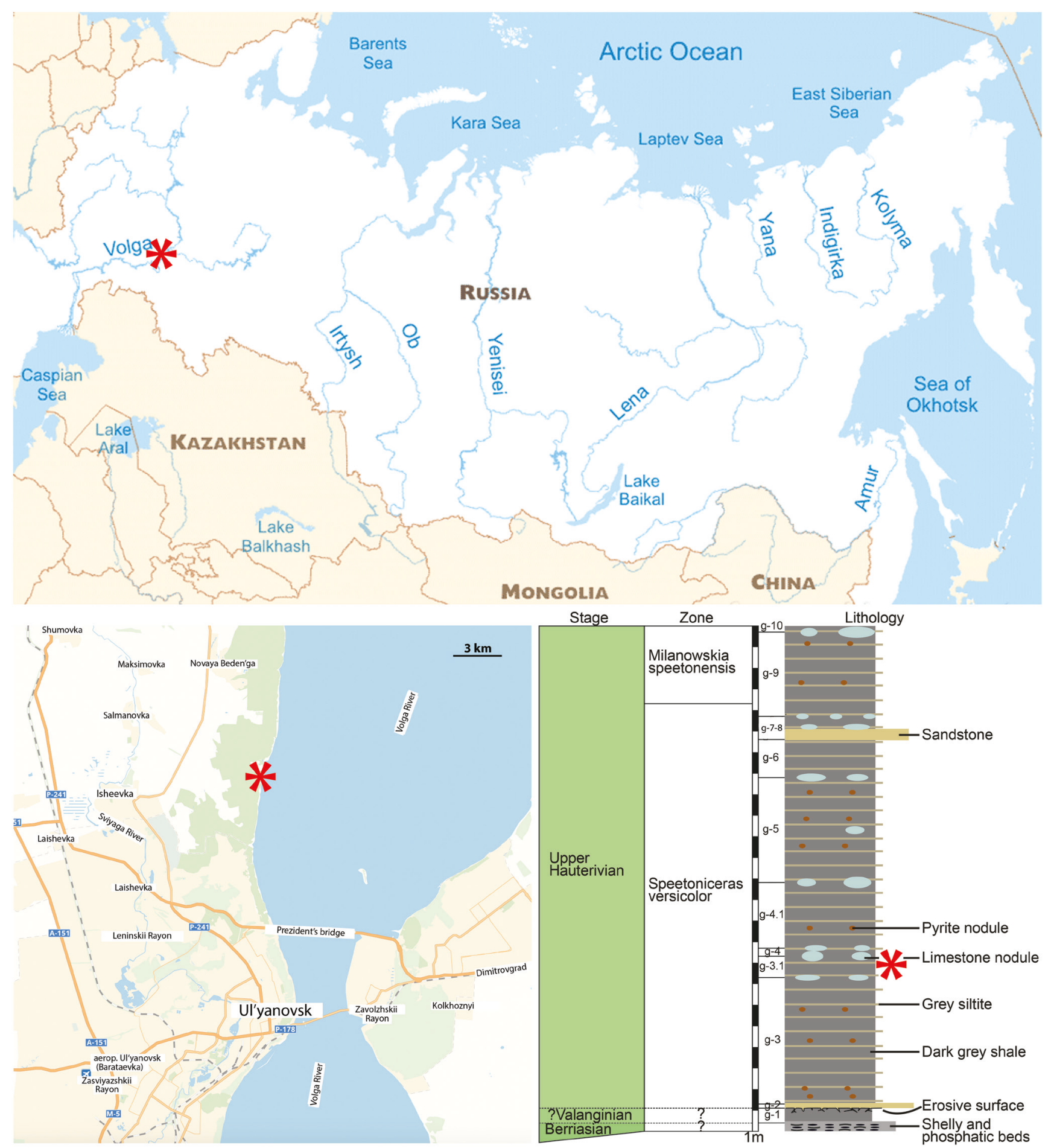

Fig. 1. Geographic position of the Slantsevy Rudnik vertebrate locality (asterisk) on the map of Russia (top) and in the vicinity of Ulyanovsk City (bottom left) and position of UPM 976 in the geological section at the Slantsevy Rudnik vertebrate locality (bottom right; modified from Fischer et al. (2017)).

condyle, somphospondylous (camellate) bone texture of caudal vertebrae, and hyposphenal ridge absent. Referred to the Lithostrotia based on a distinct rim ringing the condyle in middle caudal vertebrae. Among lithostrotians (sensu González Riga et al., 2108) it differs from Malawisaurus, Tengrisaurus, Rapetosaurus, Aeolo- saurus and Saltasauridae by a ventral ridge instead of a ventral groove in anterior and middle caudal vertebrae, from Malawisaurus and Saltasauridae - by the lack of ventrolateral ridges in anterior and middle caudal vertebrae, from Epachthosaurus and more derived lithostrotians - by the lack of tubercle on the dorsal surface 
of the transverse process in the first caudal vertebra. It differs from all sauropods except Astrophocaudia and Epachthosaurus by hyposphene-hypantrum articulations in anterior caudal vertebrae.

\section{Description}

There are seven caudal vertebrae representing anterior and middle caudals. The centrum is procoelous, with concave anterior and deeply convex, ball-like posterior articular surfaces. The posterior articular surface is symmetrical in lateral view, with the apex centered. All vertebrae have a strong ridge on the ventral centrum surface. The neural arch is incompletely preserved or totally missing. None of the preserved vertebrae show distinct chevron facets.

UPM 976/1 (Fig. 2) is the most anterior preserved caudal, most probably the first caudal in the series based on the large and vertically expanded transverse process. The centrum is massive and relatively long, with the centrum length approximately equal to the anterior centrum height (Table 1). The anterior articular surface of the centrum is teardrop-shaped. The posterior articular surface of the centrum is heart-shaped, with a concave dorsal border. In lateral view, the dorsal and ventral centrum surfaces are straight and convex, respectively.

The neural arch is confined to the anterior half of the centrum and vertical. Its anterior border is placed almost on the anterior border of the centrum. The prezygapophyses are directing anterodorsally and project completely beyond the anterior end of the centrum. The prezygapophyseal articular surfaces are slightly convex and face mediodorsally. Ventral to the prezygapophyseal facet, the medial wall of the prezygapophyseal process is distinctly concave. This concavity likely represents the hypantrum receiving a large hyposphene of the last sacral vertebra (Fig. 2E). The posterior opening of the neural canal is eggshaped, pointed dorsally (the neural canal is obscured by matrix anteriorly). The neural canal is relatively small; its height is about one third of the posterior centrum height. Just dorsal to the neural canal there is a broken posterodorsally directing outgrowth with a wedge-shaped depression on the ventral side (Fig. 2C). This outgrowth is likely a remnant of a large bifid hyposphene. Dorsal to the missing postzygapophyses there is a large and deep postspinal fossa, bounded laterally by the spinopostzygapophyseal laminae (Fig. 2C). The fossa is separated medially by a wide and robust postspinal lamina, which extends ventrally to the bottom of the postspinal fossa.

The transverse process is large, dorsoventrally expanded, and laterally projecting. Its base extends between the levels of the prezygapophysis and the midheight of the centrum. The concave dorsal margin forms a distinct prezygodiapophyseal lamina (PRDL). The ventral margin of the transverse process is slightly concave.
Table 1. Measurements (in $\mathrm{mm}$ ) of caudal vertebrae of Volgatitan simbirskiensis gen. et sp. nov. Slantsevy Rudnik, Ulyanovsk Province, Russia; Lower Cretaceous (Hauterivian). Measurements: $\mathrm{ACH}$, anterior centrum height; $\mathrm{ACW}$, anterior centrum width; $C L$, centrum length; $\mathrm{PCH}$, posterior centrum height; PCW, posterior centrum width

\begin{tabular}{c|c|c|c|c|c|c}
\hline Specimen & ACH & ACW & CL & PCH & PCW & CL/ACH \\
\hline UPM 976/1 & 209 & 222 & 205 & 206 & 223 & 0.98 \\
\hline UPM 976/2 & 204 & 234 & 184 & 191 & 213 & 0.90 \\
\hline UPM 976/3 & 196 & 230 & 175 & 182 & 184 & 0.89 \\
\hline UPM 976/4 & 232 & 215 & 218 & 209 & 181 & 0.94 \\
\hline UPM 976/5 & 188 & 204 & 229 & 185 & 204 & 1.22 \\
\hline UPM 976/6 & 186 & 188 & 225 & 152 & 182 & 1.21 \\
\hline
\end{tabular}

The anterior surface of the transverse process is slightly concave. The posterior surface of the transverse process is moderately convex, without a distinct postzygapophyseal centrodiapophyseal fossa (pocdf).

In UPM 976/2 (Fig. 3) the centrum length is slightly smaller than the anterior centrum height (Table 1). In contrast with the previous caudal, in UPM 976/2 the anterior centrum articular surface seems to be deeply incised dorsally, although this region is obscured by damage. The posterior centrum articular surface is straight dorsally (convex dorsally in UPM 976/1). The lateral centrum sides are more concave between the anterior and posterior centrum articular surfaces compared with UPM 976/1. The transverse process is more reduced; its ventral side is level with the dorsal third of the centrum. The transverse process projects laterally.

UPM $976 / 3$ (Fig. 4) is similar to UPM $976 / 2$ by dorsal margin of the centrum articular surfaces deeply incised anteriorly and straight posteriorly, and by a relatively shorter centrum, with centrum length to anterior centrum articular surface height ratio of 0.89 (Table 1). The transverse process is a blind outgrowth directed laterally and confined to the dorsal half of the centrum.

The three more posterior caudal vertebrae UPM 976/4-6 have proportionally longer centra, with centrum length to anterior centrum articular surface height ratio of $0.94,1.22$, and 1.21 , respectively (Table 1 ). In UPM 976/4 (Fig. 5A-F) and UPM 976/6 (Fig. 5L-Q), the anterior and posterior centrum articular surfaces are oval, with the long axis vertical. In UPM 976/5 (Fig. 5G-K), the anterior and posterior centrum articular surfaces are nearly circular. In contrast with the other preserved caudal vertebrae, in UPM 976/5 the apex of the posterior articular surface is separated from the rest of the posterior articular surface by a slightly concave dorsal and ventral area. UPM 976/5 and 6 differs from the more anterior caudal vertebrae in having a spool-like centrum, with the ventral and dorsal centrum surfaces concave, not straight or convex (in UPM 976/6 the dorsal centrum surface is obscured by neural arch). The 

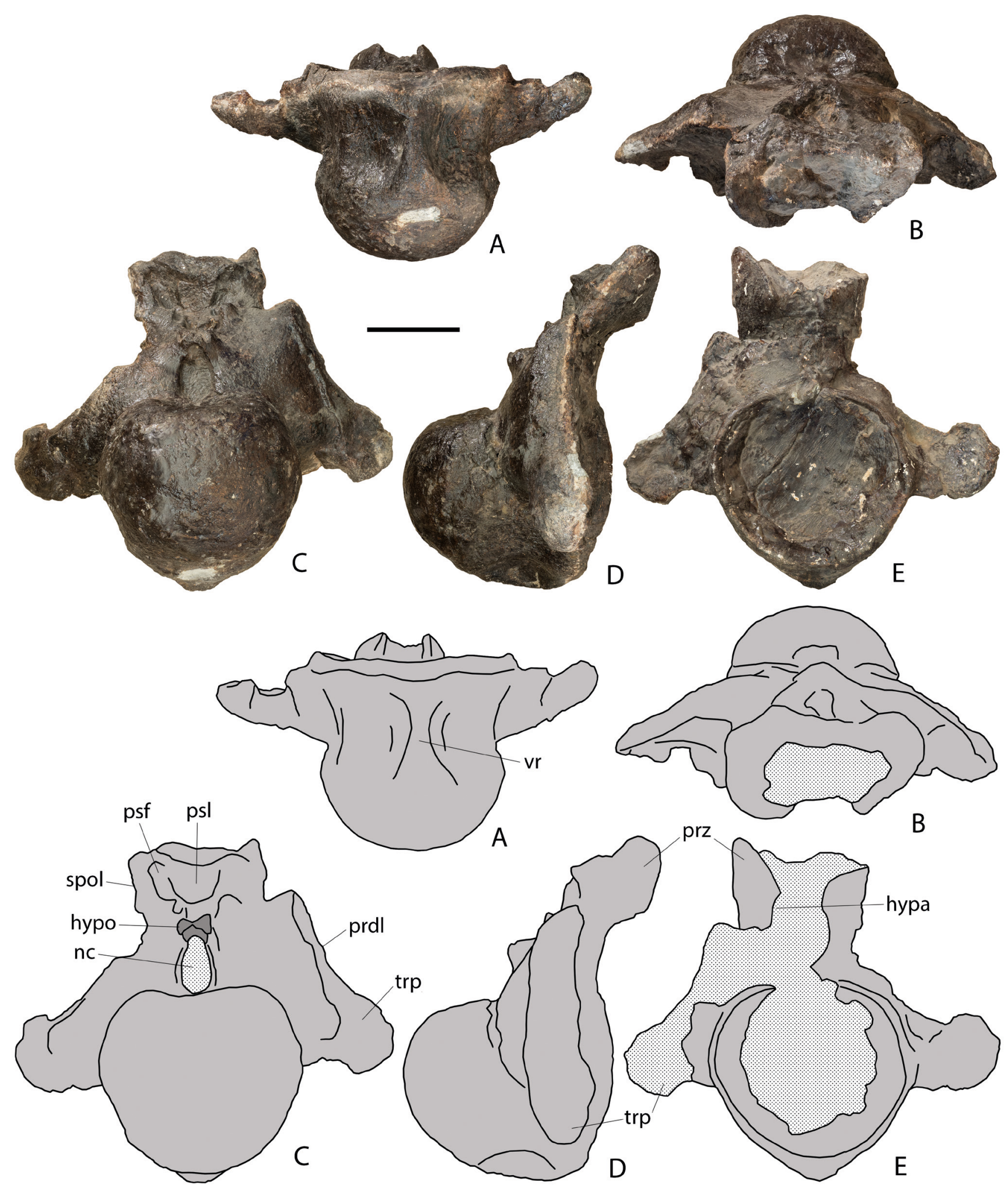

Fig. 2. Volgatitan simbirskiensis gen. et sp. nov., UPM 976/1, first caudal vertebra (holotype), in ventral (A), dorsal (B), posterior (C), lateral (D), and anterior (E) views; photographs (top) and explanatory drawings (bottom). Slantsevy Rudnik, Ulyanovsk Province, Russia; Lower Cretaceous (upper Hauterivian). Abbreviations: hypa, hypantrum; hypo, hyposphene; nc, neural canal; prdl, prezygodiapophyseal lamina; prz, prezygapophysis; psf, postspinal fossa; psl, postspinal lamina; spol, spinopostzygapophyseal lamina; trp, transverse process; vr, ventral ridge. Scale bars equals $10 \mathrm{~cm}$. 

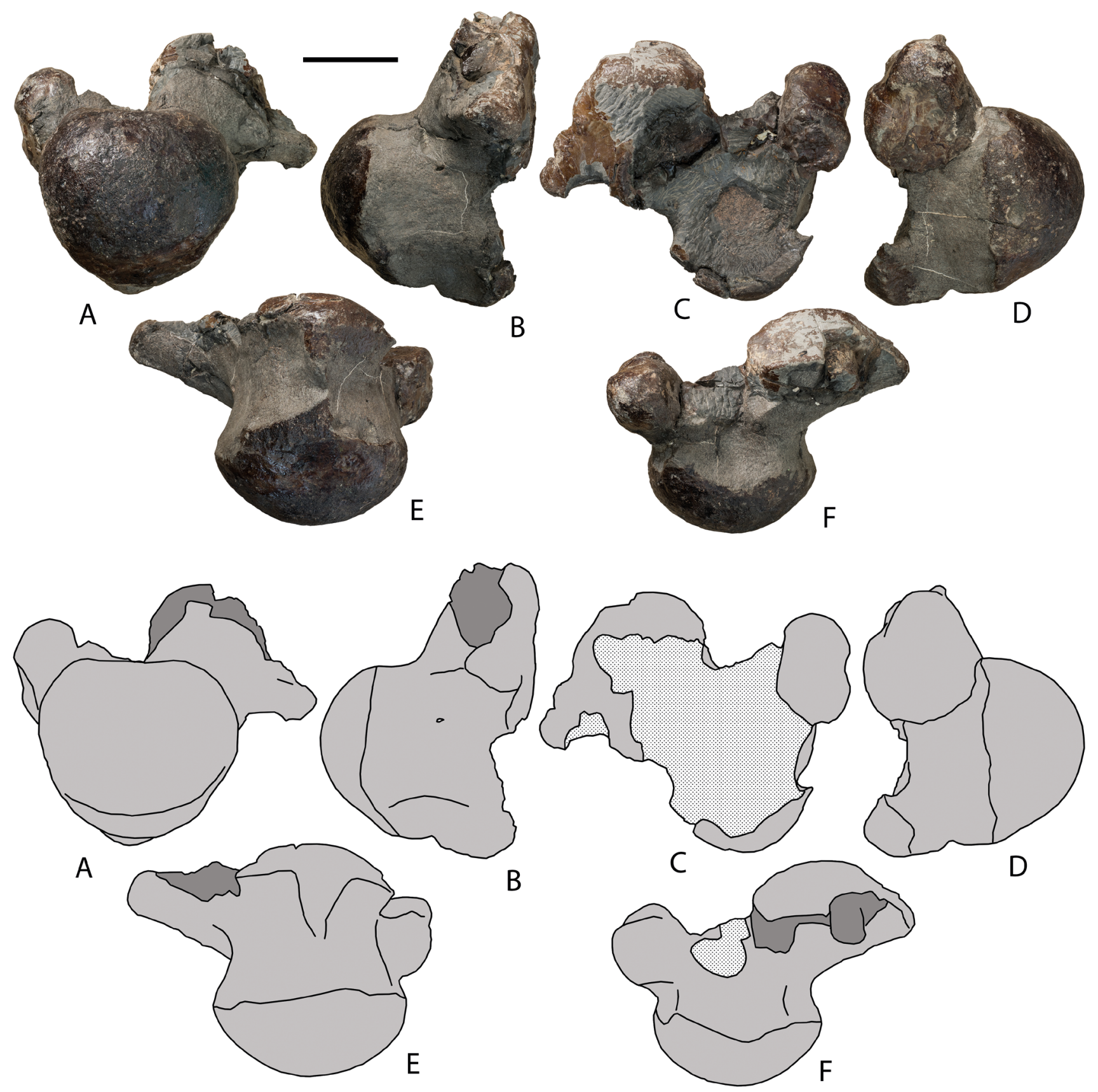

Fig. 3. Volgatitan simbirskiensis gen. et sp. nov., UPM 976/2, anterior caudal vertebra (holotype), in posterior (A), right lateral (B), anterior (C), left lateral (D), ventral (E), and dorsal (F) views; photographs (top) and explanatory drawings (bottom). Slantsevy Rudnik, Ulyanovsk Province, Russia; Lower Cretaceous (upper Hauterivian). Scale bar equals $10 \mathrm{~cm}$.

centrum is also more constricted laterally between the articular surfaces compared with the other caudal vertebrae. In UPM 976/5 and 6 the posterior centrum articular surface is circumscribed by a strong rim, separating the condyle from the lateral surface of the main body of the centrum, in contrast with the more anterior caudal vertebrae, which have a smooth transition between the centrum and its posterior articular surface. The neural arch occupies the anterior half of the centrum length in UPM 976/5 and likely in UPM 976/6 (the posterior margin of the neural arch is obscured by the matrix). In UPM 976/5 a small dorsoventrally compressed transverse process is directed more posteriorly than laterally. In UPM 976/6 the transverse process is about two times smaller compared with the previous caudal vertebra and directed posteroventrally. The transverse process is confined to the neural arch and placed dorsal to the centrum in both vertebrae.

UPM $976 / 7$ is a poorly preserved caudal centrum with teardrop-shaped anterior and posterior centrum articular surfaces. 

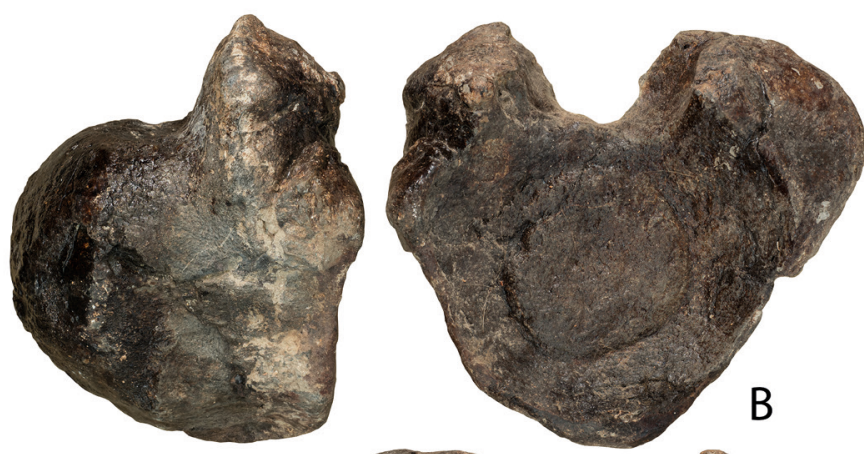

A
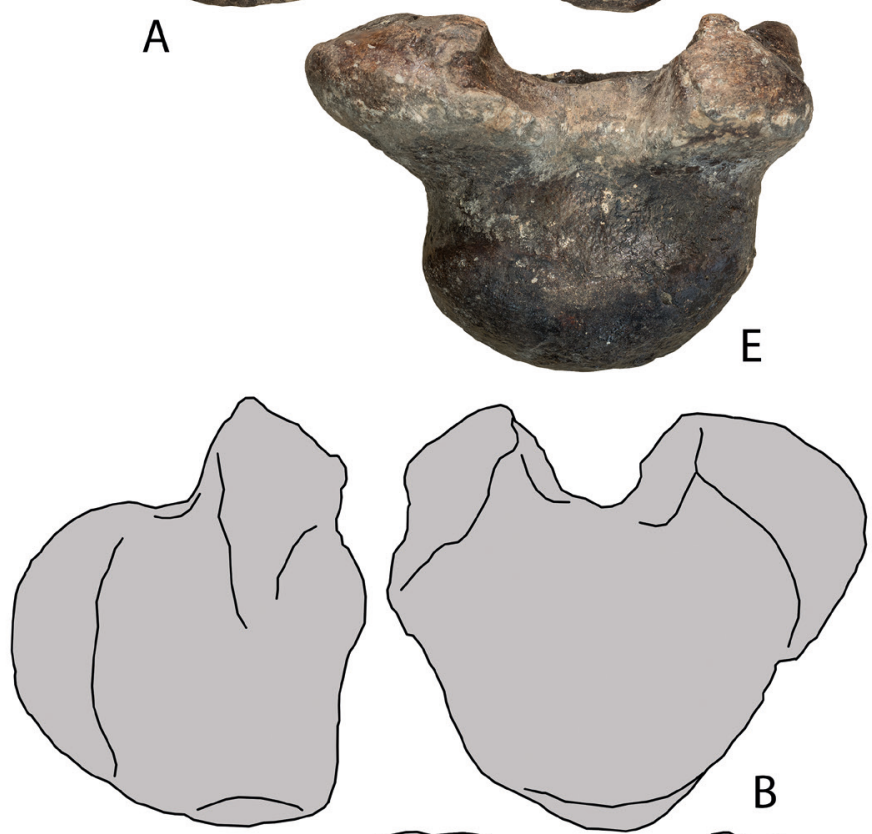

A
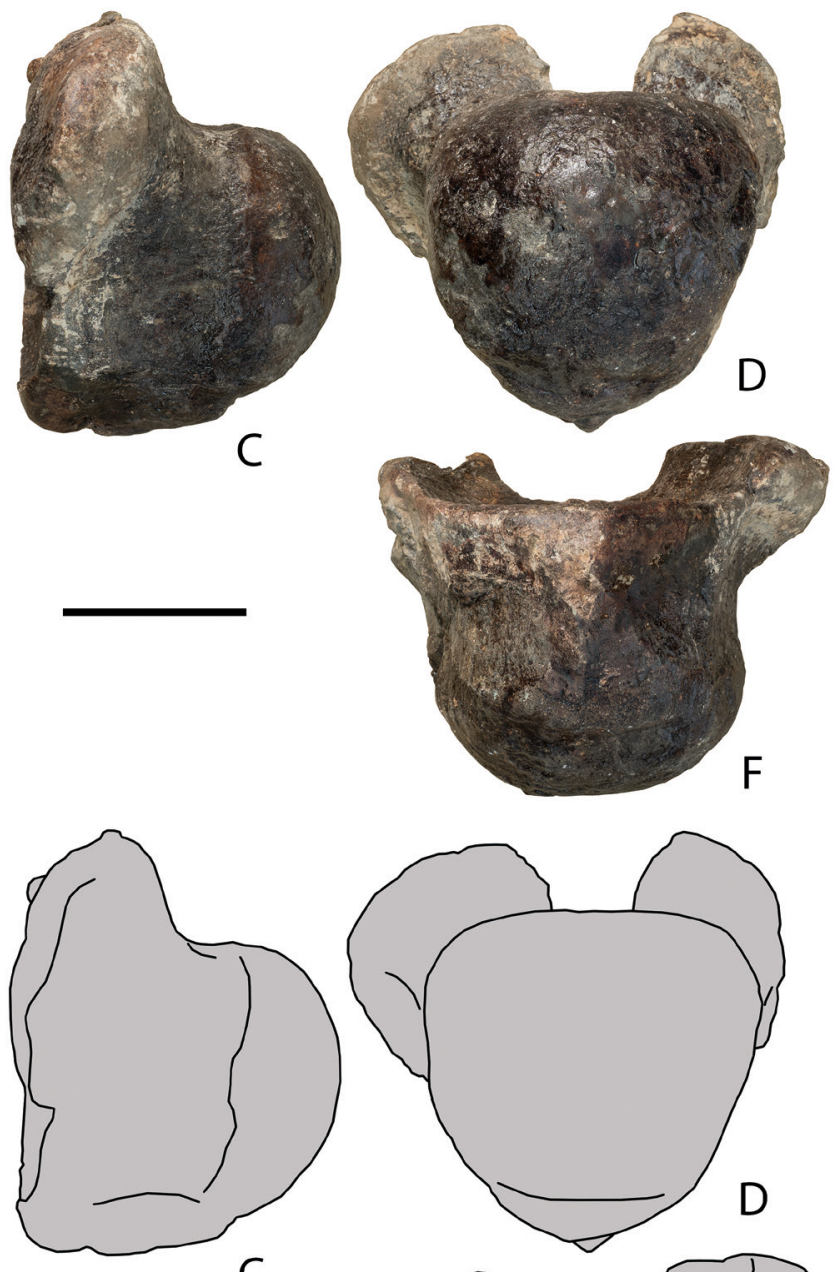

$\mathrm{C}$

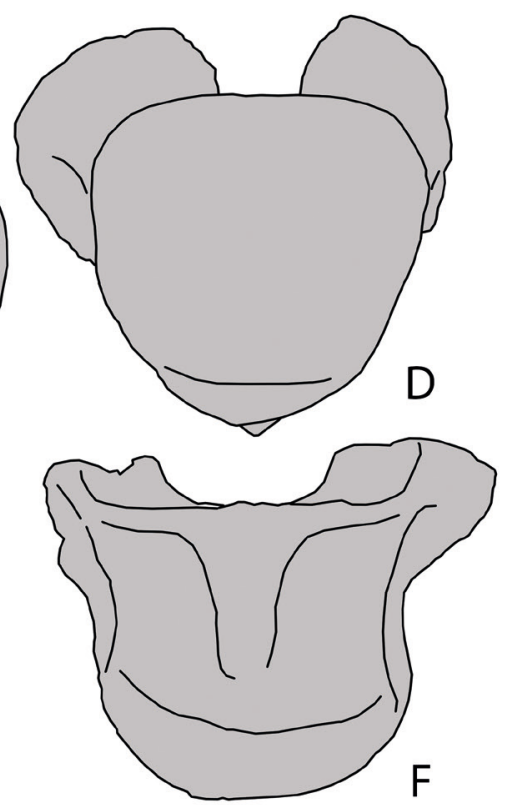

Fig. 4. Volgatitan simbirskiensis gen. et sp. nov., UPM 976/3, anterior caudal vertebra (holotype), in right lateral (A), anterior (B), left lateral (C), posterior (D), dorsal (E), and ventral (F) views; photographs (top) and explanatory drawings (bottom). Slantsevy Rudnik, Ulyanovsk Province, Russia; Lower Cretaceous (upper Hauterivian). Scale bar equals $10 \mathrm{~cm}$.

The internal camellate bone structure is revealed by the breakage in UPM 976/4 (Fig. 5B, D). It is composed of cells varying in size from 1-2 to several centimeters.

\section{Measurements - see Table 1.}

\section{Phylogenetic position of Volgatitan}

For the phylogenetic analysis we used a recent matrix of sauropods, focused on Titanosauriformes, presented by González Riga et al. (2018). We added to this matrix also the lithostrotian titanosaur Tengrisaurus recently described from the Early Cretaceous of Transbaikalia, Russia (Averianov and Skutschas, 2017). The matrix included 86 taxa and 423 characters (one character uninformative). The multistate characters $11,14,15,27$, 40, 51, 104, 122, 147, 148, 177, 195, 205 and 259 are ordered. Volgatitan gen. nov. and Tengrisaurus can be scored for $31(7.3 \%)$ and $37(8.8 \%)$ characters, respectively. The scored characters for both taxa can be found in Appendix 1. In the data matrix considered, many taxa were coded as having block-like hyposphene in ante- 


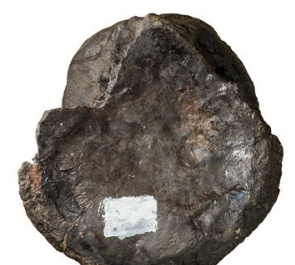

A
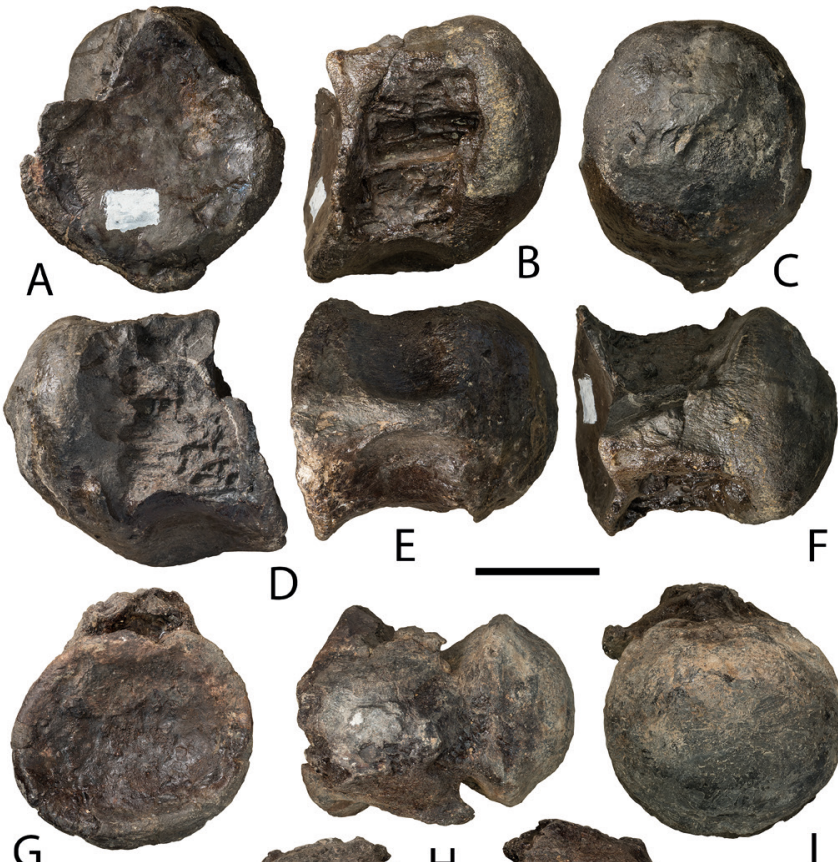

D
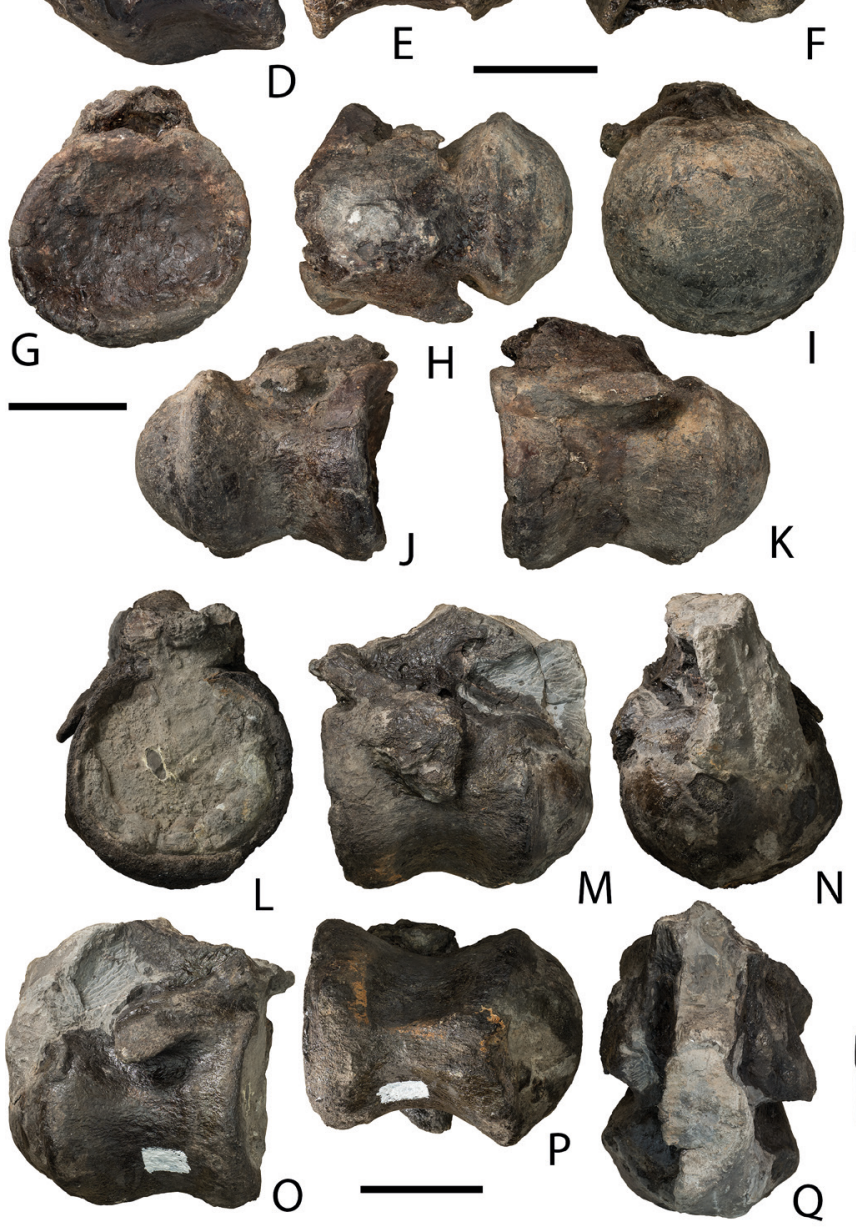
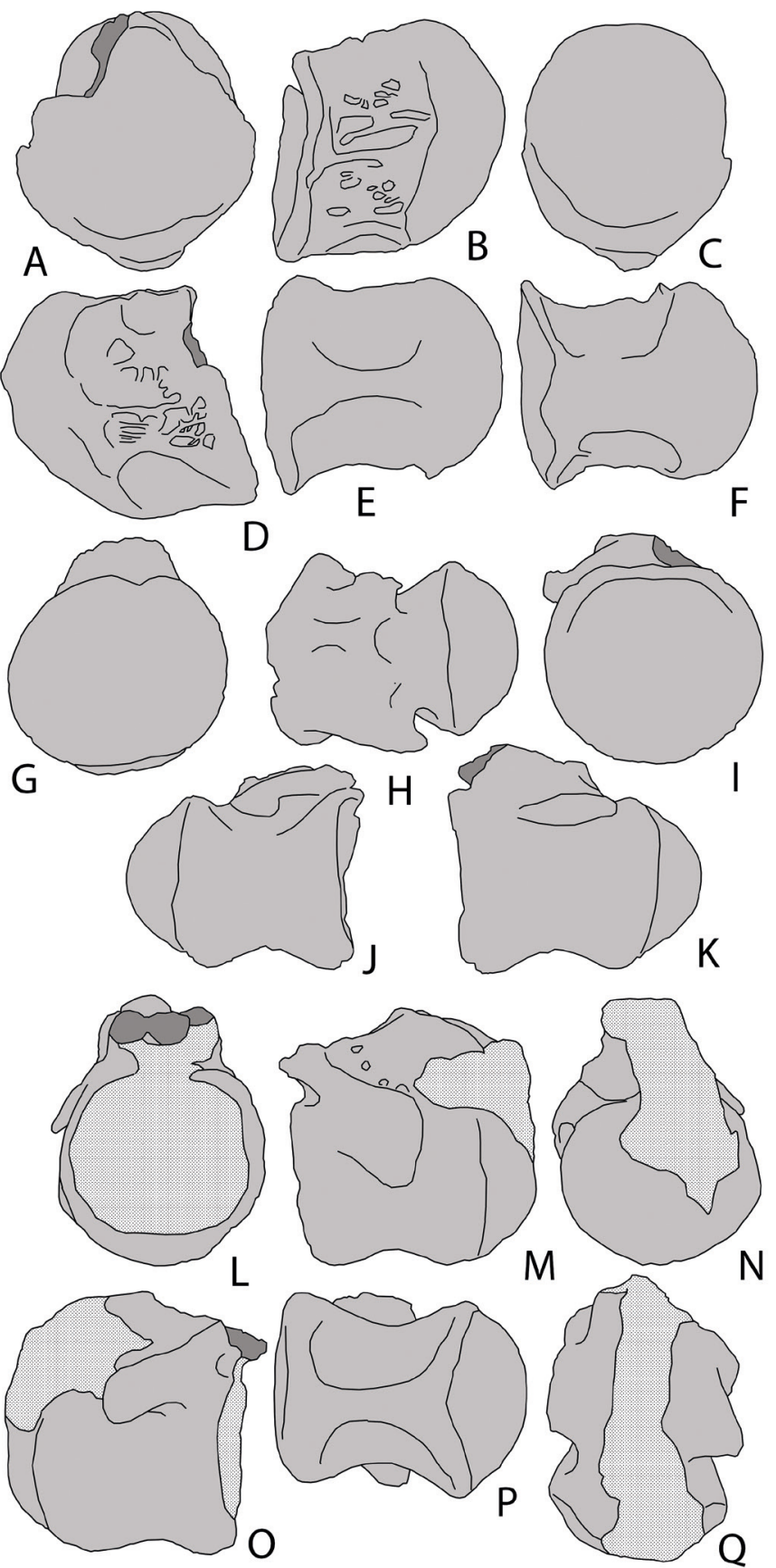

Fig. 5. Volgatitan simbirskiensis gen. et sp. nov., UPM 976/4-6, middle caudal vertebrae (holotype). A-F, UPM 976/4, in anterior (A), right lateral (B), posterior (C), left lateral (D), ventral (E), and dorsal (F) views. G-K, UPM 976/5, in anterior (G), dorsal (H), posterior (I), right lateral (J), and left lateral (K) views. L-Q, UPM 976/6, in anterior (L), left lateral (M), posterior (N), right lateral (O), ventral (P), and dorsal (Q) views. Photographs (left) and explanatory drawings (right). Slantsevy Rudnik, Ulyanovsk Province, Russia; Lower Cretaceous (upper Hauterivian). Scale bars equal 10 cm.

rior caudal neural arches (character 188(1)). Actually, this character is present only in Astrophocaudia, Epachthosaurus, and Volgatitan gen. nov. (see discussion in the next section). For all other taxa the scoring of this character was changed from one to zero. The analytical protocol of the phylogenetic analyses follows that of González Riga et al. (2018). Eight incomplete and unstable taxa were excluded from the matrix prior to the analysis (Astrophocaudia, Australodocus, Brontomerus,
Fukuititan, Fusuisaurus, Liubangosaurus, Mongolosaurus, and Tendaguria). The pruned data matrix was analyzed using the 'Stabilize Consensus' option in the 'New Technology Search' in TNT vs. 1.1 (Goloboff, Farris, and Nixon, 2008). The memory for maximum trees was changed from default 100 to 10,000 trees. Searches were carried out using sectorial searches, drift and tree fusing, with the consensus stabilized five times, prior to using the resultant trees as the starting trees for a 'Tradi- 


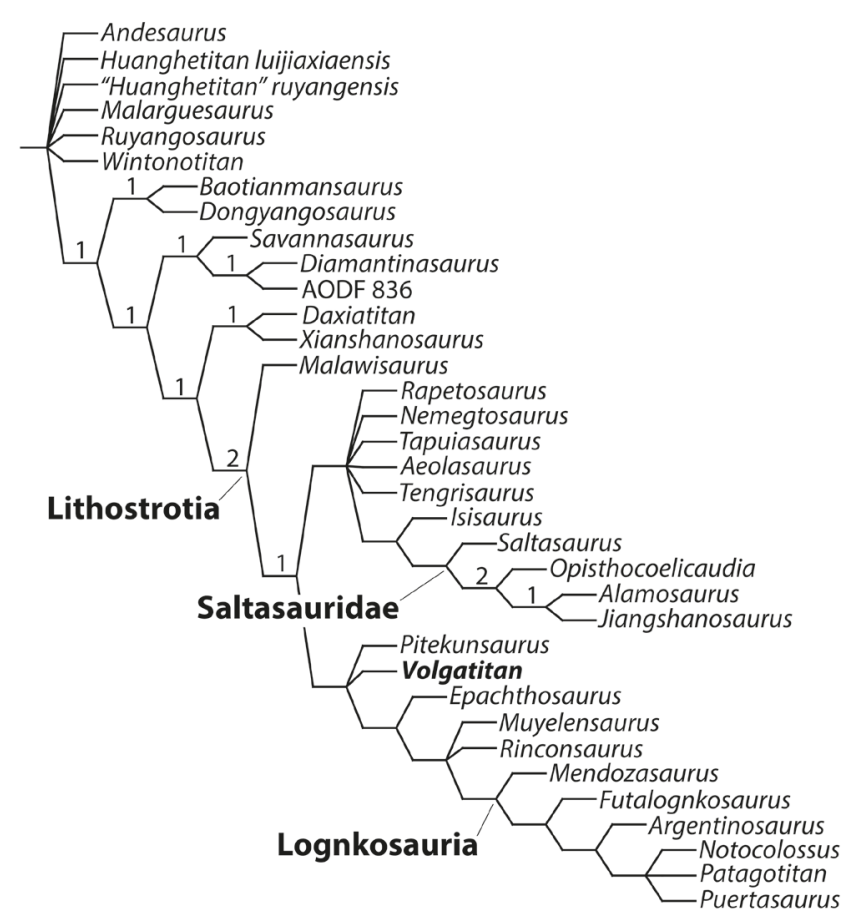

Fig. 6. Part of the strict consensus tree of 192 most parsimonious trees produced by TNT analysis, showing the interrelationships of Titanosauria including Volgatitan gen. nov. The figures at nodes are Bremer support values calculate in TNT.

tional Search' using Tree Bisection-Reconstruction. The search produced 192 most parsimonious trees with tree length of 1771 steps, consistency index of 0.25 , and retention index of 0.56 . The strict consensus tree shows a good resolution within Titanosauria (Fig. 6). As in the previous analysis (González Riga et al., 2018), the Lithostrotia is divided into two main branches: one leading to the Saltasauridae and another to the Lognkosauria. Volgatitan gen. nov. is recovered as a basal member of the second lineage. Tengrisaurus is a non-saltasaurid lithostrotian (Fig. 6), which is consistent with the previous phylogenetic analysis based on a different data matrix (Averianov and Skutschas, 2017).

Volgatitan gen. nov. has the following synapomorphies for the clade ((Daxiatitan + Xianshanosaurus) + Lithostrotia) (Fig. 6): 27(2), anterior caudal centra posterior articular surface of centrum strongly convex; 176(1), anteriormost caudal vertebrae, camellate internal tissue structure present; 177(2), anterior caudal centra, posterior articular surface convex throughout all anterior caudal vertebrae with ribs. The synapomorphies of Volgatitan gen. nov. for the clade uniting the lineages leading to the Saltasauridae and Lognkosauria are: 184(1), middle-posterior caudal centra (at least some), posterior articular surface convex; 185(1), middle-posterior caudal centra with convex posterior articular surface: distinct rim rings the condyle, separating it from the lateral surface of the main body of the centrum.

\section{Diagnostic characters of Volgatitan}

Procoelous anterior caudal centra - In Volgatitan the anterior caudals are deeply procoelous, with a distinctly concave anterior articular surface (cotyle) and a strongly convex, ball-like posterior articular surface (condyle). The procoelous anterior caudal centra are found in the Mamenchisauridae, Flagellicaudata, and Titanosauriformes (Upchurch, 1998; Wilson, 2002; Upchurch, Barrett, and Dodson, 2004a; Curry Rogers, 2005; Sekiya, 2011; Whitlock, D'Emic, and Wilson, 2011; D'Emic, 2012; Xing et al., 2015). However, in the Flagellicaudata (Dicraeosauridae + Diplodocidae) the anterior caudals are weakly procoelous, with a moderately convex posterior articular surface (Whitlock, D'Emic, and Wilson, 2011). In basal titanosauriforms the anterior caudals can be amphicoelous, platycoelous, or procoelous-opisthoplatyan (Mo et al., 2006; You, Li, Zhou, and Ji, 2006; Lü et al., 2007; González Riga, Previtera, and Pirrone, 2009; D’Emic, 2013). The ball-like posterior articulation surface of the anterior caudals, seen in Volgatitan, is more reminiscent of strongly procoelous anterior caudal vertebrae in Mamenchisauridae and Titanosauria more derived than Andesaurus.

Procoelous middle caudal centra - In Volgatitan the middle caudal centra have the same degree of procoelity as the anterior caudal centra. This contrasts the condition of Mamenchisauridae and Flagellicaudata, where the middle caudal centra are amphicoelous or amphyplatyan (Sekiya, 2011; Xing et al., 2015). In the basal titanosaurs Andesaurus and Malawisaurus the procoelous anterior caudal vertebrae are associated with amphicoelous or platycoelous middle caudal vertebrae (González Riga, Previtera, and Pirrone, 2009). The combination of procoelous anterior and middle caudal vertebrae is found only in advanced lithostrotians (Upchurch, Barrett, and Dodson, 2004a).

Length of anterior caudal centra - Most sauropods have anteroposteriorly short anterior caudal centra, with the centrum length to anterior centrum height ratio around 0.5-0.6 (Upchurch, 1998; Upchurch, Barrett, and Dodson, 2004a; Upchurch and Mannion, 2009). This ratio is close to 1.0 in basal sauropodomorphs and some advanced titanosaurs. In Volgatitan this ratio is 0.98 in the first caudal vertebra (Table 1). Among titanosaurs the long centrum of anterior caudal vertebrae is present in Mendozasaurus, Aeolasaurus, and Pellegrinisaurus (González Riga, Previtera, and Pirrone, 2009, Fig. 10).

Ventral ridge on anterior and middle caudal centra - In Volgatitan there is a prominent ventral ridge on the anterior and middle caudal centra. In advanced diplodocids and lithostrotians there is a wide and deep ventral fossa on the anterior caudal centra (Upchurch, 1998; Wilson, 2002; Upchurch, Barrett, and Dodson, 2004a; Curry Rogers, 2005; D’Emic, 2012). In saltasaurid titanosaurs this ventral fossa is present on anterior and 
middle caudal centra, where it is bounded by marked ventrolateral ridges (D'Emic and Wilson, 2011). In nonlithostrotian titanosaurs Andesaurus, Xianshanosaurus, and Dreadnoughtus at least one of the anterior caudals has a ventral ridge while in more posterior anterior caudals there is a longitudinal ventral groove bounded by ventrolateral ridges (Lü et al., 2009; Mannion and Calvo, 2011; Lacovara et al., 2014).

Position of the neural arch on the centrum - In Volgatitan the neural arch is confined to the anterior half of the centrum in the anterior and middle caudals. This is a derived condition within the Titanosauriformes (Upchurch, Barrett, and Dodson, 2004a; Curry Rogers, 2005; D'Emic, 2012). In a euhelopodid Huabeisaurus and in a basal titanosauriform Sauroposeidon the neural arch occupies most of the length of the centrum in the anteriormost caudal vertebrae, while it is positioned in the anterior part of the centrum in the middle caudal vertebrae (D'Emic and Foreman, 2012; D'Emic et al., 2013). This is apparently related to the anteroposteriorly short centra of anterior caudal vertebrae in these taxa.

Hyposphene-hypantrum complex - Hyposphene-hypantrum articulation is present in the middle and posterior dorsal vertebrae of most sauropods, except Lithostrotia (Upchurch, Barrett, and Dodson, 2004a; Apesteguía, 2005). However, in most sauropods the hyposphene-hypantrum articulation is not developed in the caudal series, where the hyposphene is replaced by the hyposphenal ridge. The only previously known sauropods which the hyposphene-hypantrum articulation extended to the caudal series are a basal titanosauriform Astrophocaudia and a basal titanosaur Epachthosaurus (Martínez et al., 2004; D'Emic, 2013). In both taxa these additional articulations are present in anterior and middle caudal vertebrae (in caudals 1-14 of Epachthosaurus). Also a small hyposphene was reported for the anterior caudal vertebrae of rebbachisaurid Demandasaurus (Torcida Fernández-Baldor et al., 2011). In Volgatitan gen. nov. the hyposphene-hypantrum articulations is present at least on the anterior caudal vertebrae. The bifid hyposphene of Volgatitan is more similar with that of Epachthosaurus.

Hyposphenal ridge - In many sauropods the postzygapophyseal facets of anterior caudal vertebrae meet ventrally and merge into a hyposphenal ridge that extends ventrally to the top of the neural canal opening (Upchurch, 1998; Upchurch, Barrett, and Dodson, 2004a). This ridge is lacking in Volgatitan and in a non neosauropod Cetiosaurus, in some rebacchisaurids and titanosauriforms, particularly in all known European titanosaurs (Upchurch and Martin, 2003; Díez Díaz, Pereda Suberbiola, and Sanz, 2013; Mannion, Upchurch, Barnes, and Mateus, 2013). The absence of the hyposphenal ridge in Volgatitan is apparently correlated with development of a hyposphene on anterior caudal vertebrae.
Postspinal fossa - The postspinal fossa is located at the base of neural spine, between the postzygapophyses, in anterior caudal vertebrae (Wilson, 2002; Upchurch, Barrett, and Dodson, 2004a). In Volgatitan the postspinal fossa is extremely large. The presence of a postspinal fossa on anterior caudal vertebrae has been considered a synapomorphy for a clade including Malawisaurus and some advanced titanosaurs (Curry Rogers, 2005).

Dorsoventrally expanded transverse process of anterior caudal vertebrae - In Volgatitan the transverse process of the first caudal is dorsoventrally expanded and extends between the level of the prezygapophyses and the midheight of the centrum. A transversely wide fan-like transverse process of anterior caudals is considered a synapomorphy for the Diplodocoidea (Upchurch, 1998; Upchurch and Mannion, 2009; Whitlock, D’Emic, and Wilson, 2011). It is present in the Flagellicaudata and variably occurs in the Rebbachisauridae. In Volgatitan the transverse process of the first caudal is not as wide transversely as in the diplodocoids and more similar with the condition present in the titanosaurs Mendozasaurus, Futalognkosaurus, Patagotitan and Lohuecotitan (Whitlock, D’Emic, and Wilson, 2011: Fig. 3; Díez Díaz et al., 2016; Carballido et al., 2017).

Transverse process in middle caudal vertebrae In sauropods the transverse process is present in the first 14-16 caudal vertebrae (Upchurch, Barrett, and Dodson, 2004a). In some titanosaurs (Opisthocoelicaudia, Alamosaurus) the transverse process disappeared by caudal 10 (Wilson, 2002; Curry Rogers, 2005). However, in a titanosaur Trigonosaurus the transverse process is present up to the 20th caudal vertebra (Campos, Kellner, Bertini, and Santucci, 2005). In Volgatitan the transverse process may have persisted longer in the caudal series compared with the most other sauropods, at it is present in the middle caudal vertebrae. The transverse process is not reduced in the middle caudals also in Saltasaurus (Powell, 1992: Fig. 23).

Internal bone structure - In Volgatitan the bone structure is evident in one middle caudal vertebra (UPM 976/4; Fig. 5B, D). It is composed of cells varying in size from 1-2 to several centimeters. Wedel, Cifelli, and Sanders (2000) proposed classification of sauropod vertebrae based on pneumatic characters. According to these authors, both camellate and somphospondylous vertebrae have internal bone structure composed entirely of camellae, but the neural arch laminae are not reduced in the former and reduced in the later. The presence of neural arch laminae is not a pneumatic character and the use of this character for classification of internal bone structure is not helpful. Other authors consider the terms somphospondylous and camellate as synonyms (Whitlock, D'Emic, and Wilson, 2011). The internal structure of UPM 976/4 lacks large camerae and can be classified as som- 
Table 2. Measurements of the first caudal centrum and body mass estimate for Eusauropoda. Groups: NNEUS, non neusauropod Eusauropoda; DIPLO, Diplodocoidea; NTMAC, non titanosaurian Macronaria; TITAN, Titanosauria. Measurements (in mm): ACH, anterior centrum height; ACW, anterior centrum width; CL, centrum length; PCH, posterior centrum height; PCW, posterior centrum width

\begin{tabular}{|c|c|c|c|c|c|c|c|c|c|}
\hline Taxon & Group & Specimen & $\begin{array}{c}\text { Body } \\
\text { mass, kg }\end{array}$ & CL & $\mathrm{ACH}$ & ACW & PCH & PCW & Reference \\
\hline Ferganasaurus verzilini & NNEUS & PIN 3042/1 & 8805 & 130 & $171^{*}$ & 195 & $206^{*}$ & 190 & Alifanov and Averianov, 2003 \\
\hline Mamenchisaurus youngi & NNEUS & ZDM 0083 & 6240 & 145 & $156^{*}$ & $112^{*}$ & $130 *$ & $72^{*}$ & Ouyang and Ye, 2002 \\
\hline Apatosaurus ajax & DIPLO & $\begin{array}{l}\text { NSMT-PV } \\
20375\end{array}$ & & 150 & 245 & 245 & $224^{*}$ & $232^{*}$ & $\begin{array}{l}\text { Upchurch, Tomida, and Barrett, } \\
2004\end{array}$ \\
\hline Apatosaurus louisae & DIPLO & CM 3018 & 41269 & 240 & $404^{*}$ & $326 *$ & $383^{*}$ & 300 & Gilmore, 1936 \\
\hline Barosaurus lentus & DIPLO & AMNH 6341 & 13164 & 153 & 283 & 300 & 295 & 265 & McIntosh, 2005 \\
\hline Comahuesaurus windhauseni & DIPLO & $\begin{array}{l}\text { MOZ-PV } \\
06741\end{array}$ & 12332 & 185 & $150 *$ & $162^{*}$ & 190 & 220 & Carballido et al., 2012 \\
\hline Demandasaurus darwini & DIPLO & MDS-RVII 605 & & 145 & 160 & 135 & 170 & $159^{*}$ & Fernández-Baldor et al., 2011 \\
\hline Dicraeosaurus hansemanni & DIPLO & $\mathrm{HMN}$ & & 130 & 201 & 200 & 208 & 190 & Janensch, 1929 \\
\hline Dicraeosaurus sattleri & DIPLO & $\mathrm{HMN}$ & 10163 & 136 & 152 & 177 & 146 & 155 & Janensch, 1929 \\
\hline Diplodocus carnegii & DIPLO & CM 84 & 13801 & 188 & $325^{*}$ & $362^{*}$ & $331 *$ & $348^{*}$ & Hatcher, 1901 \\
\hline Haplocanthosaurus delfsi & DIPLO & CMNH 10380 & & 176 & 370 & 270 & 370 & 270 & McIntosh and Williams, 1988 \\
\hline Camarasaurus lewisi & NTMAC & BYU 9047 & & 149 & 233 & 280 & 224 & 277 & $\begin{array}{l}\text { McIntosh, Miles, Cloward, and } \\
\text { Parker, } 1996\end{array}$ \\
\hline Europatitan eastwoodi & NTMAC & MDS-OTII 2 & & 145 & 310 & 260 & 320 & 290 & Fernández-Baldor et al., 2017 \\
\hline Giraffatitan brancai & NTMAC & HNM SII & 34003 & 145 & 230 & 223 & 239 & 234 & Janensch, 1950 \\
\hline Huabeisaurus allocotus & NTMAC & HBV 20001 & & 126 & 250 & 232 & 253 & 268 & D'Emic et al., 2013 \\
\hline "Huanghetitan" ruyangensis & NTMAC & 41 HIII 0001 & & 182 & 269 & 320 & $284^{*}$ & $365^{*}$ & Lü et al., 2007 \\
\hline Vouivria damparisensis & NTMAC & DAM 10 & 14627 & 88 & 193 & 197 & 182 & 196 & Mannion, Allain, and Moine, 2017 \\
\hline Baurutitan britoi & TITAN & MCT 1490-R & & 175 & 119 & 131 & $113^{*}$ & $154^{*}$ & $\begin{array}{l}\text { Kellner, Campos, and Trotta, } \\
2005\end{array}$ \\
\hline Bonitasaura salgadoi & TITAN & MPCA 460 & & 120 & $130 *$ & $197 *$ & $152^{*}$ & $188^{*}$ & Gallina and Apesteguía, 2015 \\
\hline Dreadnoughtus schrani & TITAN & MPM-PV 1156 & 59290 & $304 *$ & 250 & 320 & 310 & 310 & Lacovara et al., 2014 \\
\hline Narambuenatitan palomoi & TITAN & $\begin{array}{l}\text { MAU-PV } \\
425 / 01\end{array}$ & & 90 & $105^{*}$ & $110 *$ & $103^{*}$ & $115^{*}$ & Filippi, García, and Garrido, 2011 \\
\hline Opisthocoelicaudia skarzynskii & TITAN & $\begin{array}{c}\text { ZPAL } \\
\mathrm{MgD}-\mathrm{I} / 48\end{array}$ & 25418 & 230 & $217 *$ & $219 *$ & $219 *$ & $234^{*}$ & Borsuk-Bialynicka, 1977 \\
\hline Patagotitan mayorum & TITAN & MPEF-PV 3400 & 69092 & 340 & $405^{*}$ & $425 *$ & 400 & $413^{*}$ & Carballido et al., 2017 \\
\hline Rapetosaurus krausei & TITAN & $\begin{array}{l}\text { FMNH PR } \\
2209\end{array}$ & 1646 & 69 & 65 & 63 & 70 & 73 & Curry Rogers, 2009 \\
\hline Volgatitan simbirskiensis & TITAN & UPM 976 & & 205 & 209 & 222 & 206 & 223 & This study \\
\hline
\end{tabular}

${ }^{*}$ Calculated from the figure.

phospondylous (= camellate). The presence of somphospondylous bone texture in anterior caudal vertebrae has been considered a synapomorphy of Saltasaurinae (Whitlock, D'Emic, and Wilson, 2011). Anterior caudal vertebrae are somphospondylous also in a basal titanosauriform Jiutaisaurus (Whitlock, D'Emic, and Wilson, 2011).

\section{Proportions of the first caudal centrum in Eusauropoda}

As was noted in the previous section, Volgatitan gen. nov. has an unusually long centrum of the first caudal vertebrae. To further explore the significance of this character, we collected all available in the literature measurements 


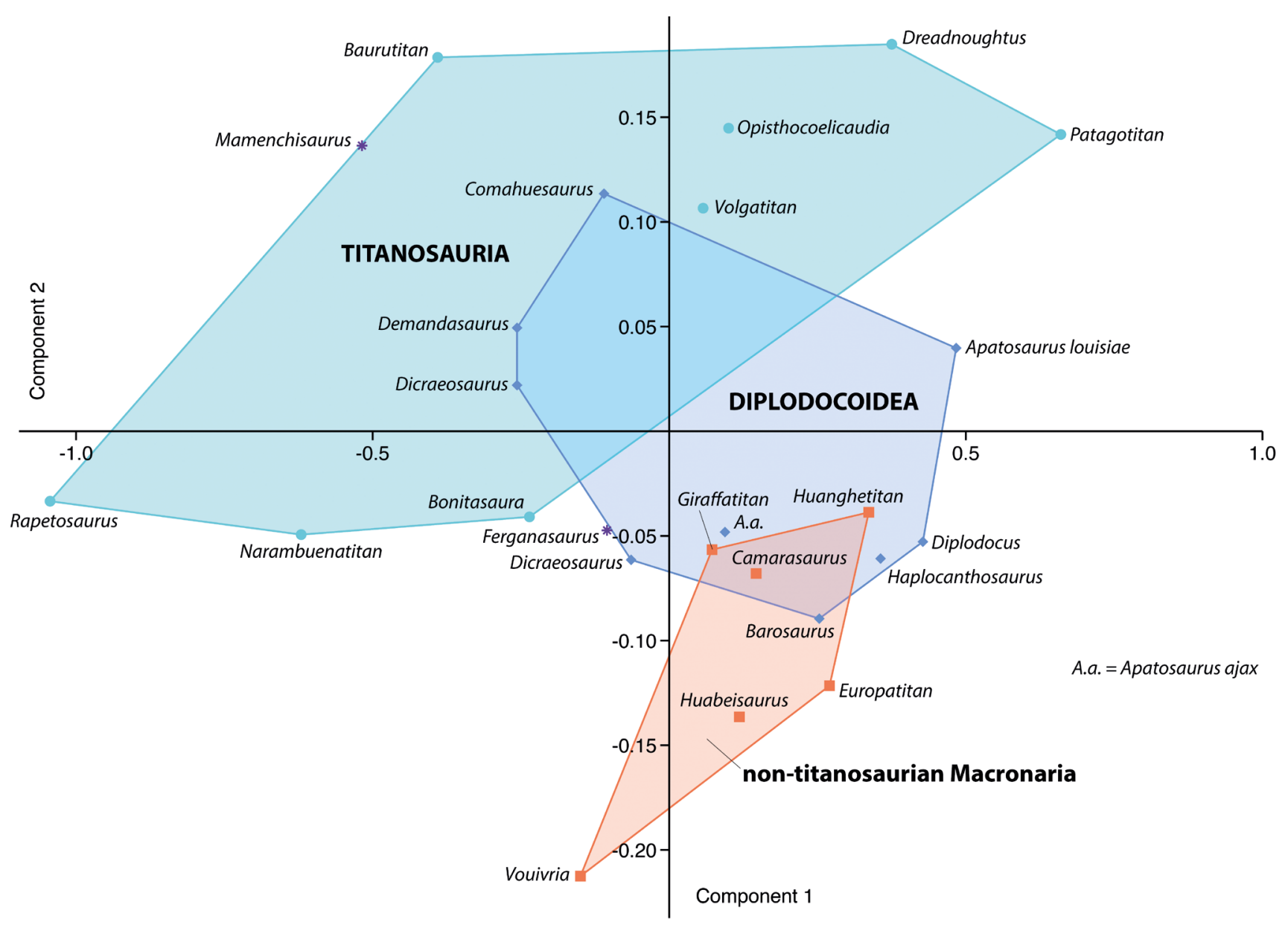

Fig. 7. Principal components analysis, components 1 and 2 of the of firs caudal measurements in Eusauropoda.

of the first caudal centrum in eusauropod taxa. Altogether, we managed to find data on 25 taxa summarized in Table 2. We examined these data using the principal components analysis (PCA) available in the PAST3 software (Hammer, Harper, and Ryan, 2001). All measurements were $\log _{10}$ transformed to account for differences in size. The first and second components (PC1 and PC2) explain $95.19 \%$ of the variance $(88.48 \%$ and

Table 3. Component loadings and eigenvalue data for PCA of the measurements of the first caudal centrum in Eusauropoda

\begin{tabular}{l|c|c|c|c}
\hline & PC1 & PC2 & PC3 & PC4 \\
\hline $\mathrm{CL}$ & 0.309 & 0.951 & -0.000 & 0.014 \\
\hline $\mathrm{ACH}$ & 0.475 & -0.171 & -0.601 & -0.043 \\
\hline $\mathrm{ACW}$ & 0.477 & -0.137 & 0.228 & -0.803 \\
\hline $\mathrm{PCH}$ & 0.481 & -0.144 & -0.315 & 0.424 \\
\hline PCW & 0.469 & -0.167 & 0.698 & 0.416 \\
\hline Eigenvalue & 0.149 & 0.11 & 0.06 & 0.01 \\
\hline \% of total variance & 88.48 & 6.71 & 3.62 & 0.88 \\
\hline
\end{tabular}

$6.71 \%$, respectively; Table 3 ). In the PC1 and PC2 scatterplot the morphospaces of Titanosauria and non-titanosaurian Macronaria are fully separated (Fig. 7). The morphospace of Diplodocoidea is partially overlapping with the two latter groups. The centrum length (CL) has the greatest loading on the PC2 while other measurements have slightly greater loading on the PC1 (Table 3 ). Volgatitan gen. nov. is placed within the morphospace of Titanosauria, close to the derived lithostrotians Opisthocoelicaudia, Dreadnoughtus, and Patagotitan, which is consistent with its phylogenetic position recovered by the phylogenetic analysis.

\section{Body size of Volgatitan}

There are two principal methods of body mass estimate in sauropods: long bone circumference and volumetric reconstruction (Bates et al., 2015; Carballido et al., 2017). Both these methods are not applicable for the body mass estimate in Volgatitan gen. nov. because of its incompleteness. To estimate the body mass in Volgatitan gen. nov. we use the measurements of the first caudal centrum and body mass estimates for the same specimens obtained by 


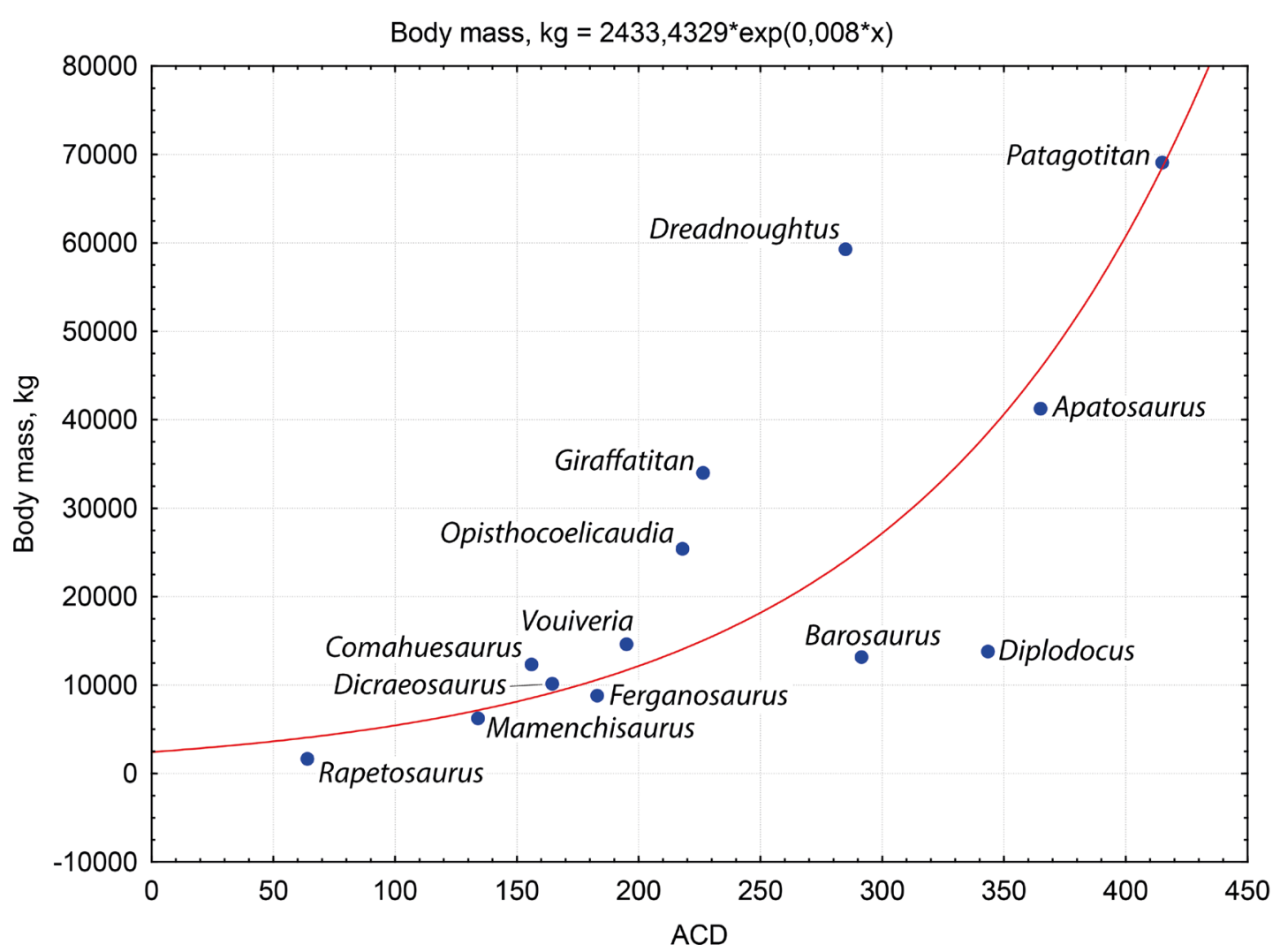

Fig. 8. Plot of body mass $(\mathrm{kg})$ and first caudal diameter of the anterior centrum articular surface $(A C D, m m)$ in Eusauropoda.

long bones scaling (Table 2). The values of body mass for Dreadnoughtus and Patagotitan are taken from Lacovara et al. (2014) and Carballido et al. (2017), respectively; for other taxa - from Benson et al. (2014). We use diameter of the anterior articular surface of the centrum $(\mathrm{ACD})$ as a proxy of the first caudal centrum size. The ACD $=(\mathrm{ACH}$ $+\mathrm{ACW}) / 2$, where $\mathrm{ACH}$ is the anterior centrum height and ACW is the anterior centrum width. The exponential fit of ACD to body mass produced the equation expressed in Fig. 8. Substitution of ACD value for Volgatitan gen. nov. $(215.5 \mathrm{~mm})$ in this equation gives the body mass of $13644 \mathrm{~kg}$ for this taxon. The linear fit of these data produced a much larger estimate of the body mass for Volgatitan gen. nov.: $20971 \mathrm{~kg}$ (the equation is Body mass = $-12526.6831+155.4413 \times \mathrm{ACD}$ ). The average of these values is $17308 \mathrm{~kg}$. This figure can be considered as a conservative body mass estimate for Volgatitan gen. nov. The Volgatitan gen. nov. is placed phylogenetically at the base of the lineage containing the largest titanosauriform sauropods with body mass of 60-70 tons: Argentinosaurus, Dreadnoughtus, Notocolossus, Patagotitan, and Puertasaurus (Bonaparte and Coria, 1993; Novas, Salgado, Calvo, and Agnolin, 2005; Lacovara et al., 2014; González Riga et al., 2016; Carballido et al., 2017). These taxa obtained gigantic size early in the history of the lineage, at the end of the Early Cretaceous, and maintained it through the whole Late Cretaceous: Al- bian (Patagotitan), Cenomanian (Argentinosaurus), Coniacian-Santonian (Notocolossus), Campanian-Maastrichtian (Dreadnoughtus), and Maastrichtian (Puertasaurus).

\section{Evolutionary History of Titanosauria}

In the Early Cretaceous the three main groups of titanosauriforms dominated in geographically different areas: brachiosaurids in North America, euhelopids in Eastern Asia, and titanosaurs in Gondwana (Mannion and Calvo, 2011; D’Emic, 2012). The lithostrotian titanosaurs split into two main groups, one which is nearly globally widespread (the clade including Saltasauridae) and another known previously to be distributed strictly in South America (the clade including Lognkosauria) (González Riga et al., 2018). Volgatitan gen. nov. is the first European and geologically oldest (Hauterivian) representative of the latter group. Its geological age and basal position within the group suggest that this lineage may have had initially a wider geographic distribution and it vanished everywhere except South America by the Late Cretaceous. The secondary dispersal of Volgatitan gen. nov. from South America to Europe seems less plausible because in South America there are no titanosaurs of this lineage older than Albian. The discovery of Volgatitan gen. nov. implies that Titanosauria may have 
had a long virtually unknown early evolutionary history in Laurasia.

\section{Acknowledgements}

We are grateful to D. V. Grigoriev for photographing the vertebrae and to Jose Carballido and two anonymous reviewers for reading the manuscript and for their corrections and suggestions. We thank N. G. Zverkov for fruitful discussion of the geology and age of the Slantsevy Rudnik vertebrate locality.

\section{References}

Alifanov, V. R. 2012. [Superorder Dinosauria]; pp. 153-309 in: [Fossil Vertebrates of Russia and Adjacent Countries. Fossil Reptiles and Birds. Part 2], edited by Kurochkin, E. N. and Lopatin, A. V. Moscow: GEOS.

Alifanov, V. R. and Averianov, A. O. 2003. Ferganasaurus verzilini, gen. et sp. nov., a new neosauropod (Dinosauria, Saurischia, Sauropoda) from the Middle Jurassic of Fergana Valley, Kirghizia. Journal of Vertebrate Paleontology 23(2):358-372. https://doi.org/10.1671/02724634(2003)023[0358:FVGESN]2.0.CO;2

Apesteguía, S. 2005. Evolution of the hyposphene-hypantrum complex within Sauropoda; pp. 248-267 in: ThunderLizards. The Sauropodomorph Dinosaurs., edited by Tidwell, V. and Carpenter, K. Bloomington and Indianapolis: Indiana University Press.

Arkhangelsky, M. S. and Averianov, A. O. 2003. On the find of a primitive hadrosauroid dinosaur (Ornithischia, Hadrosauroidea) in the Cretaceous of the Belgorod Region. Paleontological Journal 37(1):58-61.

Averianov, A. O. and Yarkov, A. A. 2004. Carnivorous dinosaurs (Saurischia, Theropoda) from the Maastrichtian of the Volga-Don Interfluve, Russia. Paleontological Journal 38(1):78-82.

Averianov, A. O. and Skutschas, P. P. 2017. A new lithostrotian titanosaur (Dinosauria, Sauropoda) from the Early Cretaceous of Transbaikalia, Russia. Biological Communications 62(1):6-18. https://doi.org/10.21638/11701/ spbu03.2017.102

Baraboshkin, E. Ye. and Blagovetshenskiy, I. V. 2010. [Reference sections of the Upper Jurassic and Lower Cretaceous of the Ulyanovsk. A guide for the field trips of 5th all-Russian conference "The Cretaceous System of Russia: problems of stratigraphy and paleogeography" (August 27-28, 2010, Ulyanovsk)]. Ulyanovsk: Ulyanovsk State University.

Baraboshkin, E.Y.e., Gorbatchik, T. N., Guzhikov, A.Y., Smirnova, S. B., Grishanov, A. N., and Kovalenko, A. A. 2001. [New data on the boundary of Hauterivian and Barremian stages (Lower Cretaceous) in Middle Volga Region]. Byuleten' Moskovskogo Obschestva Ispytatelei Prirody, Otdel Geologicheskii 76(3):31-51.

Bates, K.T., Falkingham, P. L., Macaulay, S., Brassey, C., and Maidment, S.C.R. 2015. Downsizing a giant: reevaluating Dreadnoughtus body mass. Biology Letters 11:0150215. https://doi.org/10.1098/rsbl.2015.0215

Benson, R.B.J., Campione, N.E., Carrano, M.T., Mannion, P.D., Sullivan, C., Upchurch, P., and Evans, D.C. 2014. Rates of dinosaur body mass evolution indicate 170 million years of sustained ecological innovation on the avian stem lineage. PLoS Biology 12(5):e1001853. https://doi.org/10.1371/journal.pbio.1001853

Blagovetshenskiy, I. V. and Shumilkin, I. A. 2006a. Gastropod mollusks from the Hauterivian of Ulyanovsk (Volga region): 1. Family Aporrhaidae. Paleonto- logical Journal 40(1):34-45. https://doi.org/10.1134/ S0031030106010047

Blagovetshenskiy, I. V. and Shumilkin, I. A. 2006b. Gastropod mollusks from the Hauterivian of Ulyanovsk (Volga region): 2. Genera Khetella Beisel, 1977 and Cretadmete gen. nov. Paleontological Journal 40(2):143-149. https:// doi.org/10.1134/S0031030106020043

Bonaparte, J. F. and Coria, R. A. 1993. Un nuevo y gigantesco saurópodo titanosaurio de la Formación Río Limay (Albiano-Cenomanio) de la Provincia del Neuquén, Argentina. Ameghiniana 30(3):271-282.

Borsuk-Bialynicka, M. 1977. A new camarasaurid sauropod Opisthocoelicaudia skarzynskii, gen. n., sp. n. from the Upper Cretaceous of Mongolia. Palaeontologia Polonica 37:1-64.

Campos, D.A., Kellner, A.W.A., Bertini, R.J., and Santucci, R. M. 2005. On a titanosaurid (Dinosauria, Sauropoda) vertebral column from the Bauru Group, Late Cretaceous of Brazil. Arquivos do Museu Nacional, Rio de Janeiro 63(3):565-593.

Carballido, J. L., Salgado, L., Pol, D., Canudo, J. I., and Garrido, A. 2012. A new basal rebbachisaurid (Sauropoda, Diplodocoidea) from the Early Cretaceous of the Neuquén Basin; evolution and biogeography of the group. Historical Biology 24(6):631-654. https://doi.org/10.1080 /08912963.2012.672416

Carballido, J. L., Pol, D., Otero, A., Cerda, I. A., Salgado, L., Garrido, A. C., Ramezani, J., Cúneo, N. R., and Krause, J. M. 2017. A new giant titanosaur sheds light on body mass evolution among sauropod dinosaurs. Proceedings of the Royal Society B: Biological Sciences 284(1860):20171219. https://doi.org/10.1098/rspb.2017.1219

Chernova, E. S. 1951. [On age and subdivision simbirskites layers and belemnite strata of Vlga Region]. Byuleten' Moskovskogo Obschestva Ispytatelei Prirody, Otdel Geologicheskii 26(6):46-81.

Curry Rogers, K. A. 2005. Titanosauria: a phylogenetic overiview; pp. 50-193 in: The Sauropods. Evolution and Paleobiology, edited by Curry Rogers, K. A. and Wilson, J. A. Berkeley, Los Angeles, London: University of California Press.

Curry Rogers, K.A. 2009. The postcranial osteology of Rapetosaurus krausei (Sauropoda: Titanosauria) from the Late Cretaceous of Madagascar. Journal of Vertebrate Paleontology 29(4):1046-1086. https://doi. org/10.1671/039.029.0432

D'Emic, M. D. 2012. The early evolution of titanosauriform sauropod dinosaurs. Zoological Journal of the Linnean Society 166(3):624-671. https://doi.org/10.1111/j.10963642.2012.00853.x

D'Emic, M. D. 2013. Revision of the sauropod dinosaurs of the Lower Cretaceous Trinity Group, southern USA, with the description of a new genus. Journal of Systematic Palaeontology 11(6):707-726. https://doi.org/10.1080/147720 19.2012 .667446

D'Emic, M. D. and Wilson, J. A. 2011. New remains attributable to the holotype of the sauropod dinosaur Neuquensaurus australis, with implications for saltasaurine systematics. Acta Palaeontologica Polonica 56(1):61-73. https:// doi.org/10.4202/app.2009.0149

D'Emic, M. D. and Foreman, B. Z. 2012. The beginning of the sauropod dinosaur hiatus in North America: insights from the Lower Cretaceous Cloverly Formation of Wyoming. Journal of Vertebrate Paleontology 32(4):883-902. https://doi.org/10.1080/02724634.2012.671204

D'Emic, M. D., Mannion, P.D., Upchurch, P., Benson, R. B.J., Pang, Q., and Cheng, Z. 2013. Osteology of Huabeisaurus allocotus (Sauropoda: Titanosauriformes) from the Up- 
per Cretaceous of China. PLoS One 8(8):e69375. https:// doi.org/10.1371/journal.pone.0069375

Díez Díaz, V., Pereda Suberbiola, X., and Sanz, J. L. 2013. The axial skeleton of the titanosaur Lirainosaurus astibiae (Dinosauria: Sauropoda) from the latest Cretaceous of Spain. Cretaceous Research 43:145-160. https://doi. org/10.1016/j.cretres.2013.03.002

Díez Díaz, V., Mocho, P., Páramo, A., Escaso, F., Marcos-Fernández, F., Sanz, J. L., and Ortega, F. 2016. A new titanosaur (Dinosauria, Sauropoda) from the Upper Cretaceous of Lo Hueco (Cuenca, Spain). Cretaceous Research 68:4960. https://doi.org/10.1016/j.cretres.2016.08.001

Efimov, D. V. 2001. [Dinosaur remains in Lower Cretaceous deposits of Ulyanovsk Province]; p. 111 in: [Geologists of XXI Century. Abstracts of Regional Scientific Conference of Students, Aspirants, and Young Specialists. Saratov, March 26-28, 2001]. Saratov.

Efimov, D. V. 2016. [Catalogue of dinosaur localities in Middle Volga Region]; pp. 192-193 in: [Treshnikov's Readings 2016], edited by llina, N. A. Ulyanovsk.

Efimov, V. M. 1987. [Marine reptiles in Mesozoic deposits of Ulyanovsk Province]. Kraevedcheskie Zapiski 7:60-66.

Efimov, V. M. 1997a. A new genus of ichthyosaurs from the Late Cretaceous of the Ulyanovsk Volga Region. Paleontological Journal 31(4):422-426.

Efimov, V. M. 1997b. On a find of a fossil sauropod from the marine Hauterivian of the middle Volga Region. Paleontological Journal 31(6):653-654.

Efimov, V. M. and Efimov, D. V. 2015. [Dinosaur remains findings in Middle Volga]; pp. 77-79 in: [Hundred Years of Study of Amur Dinosaurs: A Scientific Session Devoted to Outstanding Paleontologists and geologist A. N. Ryabinin. Abstracts]. Blagoveschensk: Amur NTS DVO RAN.

Filippi, L. S., García, R. A., and Garrido, A. G. 2011. A new titanosaur sauropod dinosaur from the Upper Cretaceous of North Patagonia, Argentina. Acta Palaeontologica Polonica 56(3):505-520. https://doi.org/10.4202/ app.2010.0019

Fischer, V., Arkhangelsky, M.S., Stenshin, I. M., Uspensky, G. N., Zverkov, N. G., and Benson, R. B. J. 2015. Peculiar macrophagous adaptations in a new Cretaceous pliosaurid. Royal Society Open Science 2:150552. https:// doi.org/10.1098/rsos.150552

Fischer, V., Benson, R. B. J., Zverkov, N. G., Soul, L. C., Arkhangelsky, M. S., Lambert, O., Stenshin, I. M., Uspensky, G. N., and Druckenmiller, P.S. 2017. Plasticity and convergence in the evolution of short-necked plesiosaurs. Current Biology 27(11):1667-1676. https://doi.org/10.1016/j. cub.2017.04.052

Gallina, P. A. and Apesteguía, S. 2015. Postcranial anatomy of Bonitasaura salgadoi (Sauropoda, Titanosauria) from the Late Cretaceous of Patagonia. Journal of Vertebrate Paleontology 35(3):e924957. https://doi.org/10.1080/027246 34.2014 .924957

Gilmore, C.W. 1936. Osteology of Apatosaurus with special reference to specimens in the Carnegie Museum. Memoirs of the Carnegie Museum 11:175-300.

Glazunova, A. E. 1967. [New records of Cretaceous ammonites on Russian Platform]. Trudy Vsesoyuznogo nauchnoissledovatelskogo geologicheskogo instituta, Novaya seriya 129:156-165.

Glazunova, A. E. 1973. [Paleontological Justification of Stratigraphic Patrition of the Cretaceous Deposits of Volga Region. Lower Cretaceous]. Moscow: Nedra.

Goloboff, P. A., Farris, J. S., and Nixon, K. C. 2008. TNT (Tree analysis using New Technology) (BETA). Tucamán, Argentina: Published by the authors.
González Riga, B.J., Previtera, E., and Pirrone, C. A. 2009. Malarguesaurus florenciae gen. et sp. nov., a new titanosauriform (Dinosauria, Sauropoda) from the Upper Cretaceous of Mendoza, Argentina. Cretaceous Research 30(1):135-148. https://doi.org/10.1016/j.cretres.2008.06.006

González Riga, B.J., Lamanna, M. C., Ortiz David, L. D., Calvo, J. O., and Coria, J.P. 2016. A gigantic new dinosaur from Argentina and the evolution of the sauropod hind foot. Scientific Reports 6:19165. https://doi.org/10.1038/ srep19165

González Riga, B. J., Mannion, P. D., Poropat, S. F., Ortiz David, L. D., and Coria, J. P. 2018. Osteology of the Late Cretaceous Argentinean sauropod dinosaur Mendozasaurus neguyelap: implications for basal titanosaur relationships. Zoological Journal of the Linnean Society 184(1):136181. https://doi.org/10.1093/zoolinnean/zlx103

Guzhikov, A. Y., Baraboshkin, E. Ye., and Birbina, A. V. 2003. New paleomagnetic data for the Hauterivian - Aptian deposits of the Middle Volga region: A possibility of global correlation and dating of time-shifting of stratigraphic boundaries. Russian Journal of Earth Sciences 5(6):1-14.

Hammer, Ø., Harper, D. A. T., and Ryan, P. D. 2001. PAST: Paleontological statistics software package for education and data analysis. Palaeontologia Electronica 4(1):9.

Hatcher, J. B. 1901. Diplodocus (Marsh): Its osteology, taxonomy, and probable habits, with a restoration of the skeleton. Memoirs of the Carnegie Museum 1:1-63.

Janensch, W. 1929. Die Wirbelsäule der Gattung Dicraeosaurus. Palaeontographica Supplementbände Band SVII(1):35-133.

Janensch, W. 1950. Die Wirbelsäule von Brachiosaurus brancai. Palaeontographica, Abteilung A: Palaozoologie, Stratigraphie 3 (Suppl. 7 Reihe 1):27-93.

Kellner, A. W. A., Campos, D. A., and Trotta, M. N. F. 2005. Description of a titanosaurid caudal series from the Bauru Group, Late Cretaceous of Brazil. Arquivos do Museu Nacional, Rio de Janeiro 63(3):529-564.

Lacovara, K.J., Lamanna, M.C., Ibiricu, L. M., Poole, J.C., Schroeter, E. R., Ullmann, P.V., Voegele, K. K., Boles, Z. M., Carter, A. M., Fowler, E. K., Egerton, V. M., Moyer, A. E., Coughenour, C. L., Schein, J. P., Harris, J. D., Martínez, R. D., and Novas, F. E. 2014. A gigantic, exceptionally complete titanosaurian sauropod dinosaur from Southern Patagonia, Argentina. Scientific Reports 4:6196. https://doi.org/10.1038/srep06196

Lü, J., Xu, L., Zhang, X., Hu, W., Wu, Y., Jia, S., and Ji, Q. 2007. A new gigantic sauropod dinosaur with the deepest known body cavity from the Cretaceous of Asia. Acta Geologica Sinica 81(2):167-176. https://doi. org/10.1111/j.1755-6724.2007.tb00941.x

Lü, J., Xu, L., Jiang, X., Jia, S., Li, M., Yuan, C., Zhang, X., and Ji, Q. 2009. A preliminary report on the new dinosaurian fauna from the Cretaceous of the Ruyang Basin, Henan Province of central China. Journal of the Paleontological Society of Korea 25(1):43-56.

Mannion, P. D. and Calvo, J. O. 2011. Anatomy of the basal titanosaur (Dinosauria, Sauropoda) Andesaurus delgadoi from the mid-Cretaceous (Albian-early Cenomanian) Río Limay Formation, Neuquén Province, Argentina: implications for titanosaur systematics. Zoological Journal of the Linnean Society 163(1):155-181. https://doi.org/10.1111/ j.1096-3642.2011.00699.x

Mannion, P. D., Allain, R., and Moine, O. 2017. The earliest known titanosauriform sauropod dinosaur and the evolution of Brachiosauridae. Peer] 5:e3217. https://doi. org/10.7717/peerj.3217 
Mannion, P. D., Upchurch, P., Barnes, R. N., and Mateus, O. 2013. Osteology of the Late Jurassic Portuguese sauropod dinosaur Lusotitan atalaiensis (Macronaria) and the evolutionary history of basal titanosauriforms. Zoological Journal of the Linnean Society 168(1):98-206. https:// doi.org/10.1111/zoj.12029

Martínez, R.D., Gimenez, O., Rodriguez, J., Luna, M., and Lamanna, M. C. 2004. An articulated specimen of the basal titanosaurian (Dinosauria: Sauropoda) Epachthosaurus sciuttoi from the early Late Cretaceous Bajo Barreal Formation of Chubut Province, Argentina. Journal of Vertebrate Paleontology 24(1):107-120. https://doi. org/10.1671/9.1

McIntosh, J. S. 2005. The genus Barosaurus Marsh (Sauropoda, Diplodocidae); pp. 38-77 in: The Sauropod Dinosaurs, edited by Tidwell, V. and Carpenter, K. Bloomington: Indiana University Press.

McIntosh, J.S. and Williams, M. E. 1988. A new species of sauropod dinosaur, Haplocanthosaurus delfsi sp. nov., from the Upper Jurassic Morrison Fm. of Colorado. Kirtlandia 43:3-26.

McIntosh, J. S., Miles, C. A., Cloward, K. C., and Parker, J. 1996. A new nearly complete skeleton of Camarasaurus. Bulletin of Gunma Museum of Natural History 1:1-87.

Mo, J.-Y., Wang, W., Huang, Z., Huang, X., and Xu, X. 2006. A basal titanosauriform from the Early Cretaceous of Guangxi, China. Acta Geologica Sinica 80(4):486-489. https://doi.org/10.1111/j.1755-6724.2006.tb00267.x

Moskvin, M. M. 1986. [Stratigraphy of the USSR. Cretaceous System. Semivolume 1]. Moscow: Nedra.

Myatlyuk, E. V. 1984. [Hauterivian foraminifers of Middle Volga Region]; pp. 74-85 in: [Microfauna of oil and gas bearing regions of the USSR], edited by Lyubimova, P.S. and Myatlyuk, E. V. Leningrad: Izdatelstvo VNIGRI.

Nesov, L. A. 1995. [Dinosaurs of Northern Eurasia: New Data about Assemblages, Ecology and Paleobiogeography]. Saint Petersburg: Izdatelstvo Sankt-Peterburgskogo Universiteta.

Novas, F. E., Salgado, L., Calvo, J. O., and Agnolin, F. L. 2005. Giant titanosaur (Dinosauria, Sauropoda) from the Late Cretaceous of Patagonia. Revista del Museo Argentino de Ciencias Naturales 7(1):37-41.

Ouyang, H. and Ye, Y. 2002. The First Mamenchisaurian Skeleton with Complete Skull, Mamenchisaurus youngi. Chengdu: Sichuan Science and Technology Press.

Pavlow, A. P. 1901. Le Crétacé inférieur de la Russie et sa faune. Premère partie. Aperçu historique des recherches, suivi d'indications sur la distribution des mers et des terres aux différentes époques. Seconde partie. Cephalopodes du Néocomien supérieur du type de Simbirsk. Nouveaux mémoires de la Société impériale des naturalistes de Moscou 16(3):1-87.

Pavlow, A. P. and Lamplugh, G. W. 1892. Les Argiles de Speeton et laurs équivalents. Bulletin de la Société impériale des naturalistes de Moscou, nouvelle série 5:181-276, 455-570.

Powell, J. E. 1992. Osteologia de Saltasaurus loricatus (Sauropoda-Titanosauroda) del Cretacico Superior del Noreostre Argentino; pp. 165-230 in: Los Dinosaurios y Su Entorno Biotico: Actas del Segundo Curso de Paleontologia in Cuenca, edited by Sanz, J. L. and Buscalioni, A. D. Cuenca, Argentina: Instituto "Juan de Valdes" Excmo.

Riabinin, A. N. 1945. [Dinosaurian remains from the Upper Cretaceous of the Crimea]. Materialy Vsesoyuznogo Nauchno-Issledovatel'skogo Geologicheskogo Instituta. Paleontologiya i Stratigrafiya (4):4-10.

Sazonova, I. G. 1958. [Lower Cretaceous deposits of central regions of Russian Platform]; pp. 31-184 in: [Mesozoic and Tertiary deposits of central regions of Russian Platform], edited by Flerova, O. V. Moscow: Gostoptekhizdat.

Sekiya, T. 2011. Re-examination of Chuanjiesaurus anaensis (Dinosauria: Sauropoda) from the Middle Jurassic Ch- uanjie Formation, Lufeng County, Yunnan Province, southwest China. Memoir of the Fukui Prefectural Dinosaur Museum 10:1-54.

Torcida Fernández-Baldor, F. T., Canudo, J. I., Huerta, P., Montera, D., Pereda Suberbiola, X., and Salgado, L. 2011. Demandasaurus darwini, a new rebbachisaurid sauropod from the Early Cretaceous of the Iberian Peninsula. Acta Palaeontologica Polonica 56(3):535-552. https://doi. org/10.4202/app.2010.0003

Torcida Fernández-Baldor, F. T., Canudo, J. I., Huerta, P., Moreno-Azanza, M., and Montero, D. 2017. Europatitan eastwoodi, a new sauropod from the lower Cretaceous of Iberia in the initial radiation of somphospondylans in Laurasia. PeerJ 5:e3409. https://doi.org/10.7717/peerj.3409

Upchurch, P. 1998. The phylogenetic relationships of sauropod dinosaurs. Zoological Journal of the Linnean Society 124(1):43-103. https://doi.org/10.1111/j.1096-3642.1998. tb00569.x

Upchurch, P. and Martin, J. 2003. The anatomy and taxonomy of Cetiosaurus (Saurischia, Sauropoda) from the Middle Jurassic of England. Journal of Vertebrate Paleontology 23(1):208-231. https://doi.org/10.1671/02724634(2003)23[208:TAATOC]2.0.CO;2

Upchurch, P. and Mannion, P. D. 2009. The first diplodocid from Asia and its implications for the evolutionary history of sauropod dinosaurs. Palaeontology 52(6):1195-1207. https://doi.org/10.1111/j.1475-4983.2009.00909.x

Upchurch, P., Barrett, P. M., and Dodson, P. 2004a. Sauropoda; pp. 259-322 in: The Dinosauria. Second Edition, edited by Weishampel, D. B., Dodson, P., and Osmolska, H. Berkeley, Los Angeles, London: University of California Press.

Upchurch, P., Tomida, Y., and Barrett, P. M. 2004b. A new specimen of Apatosaurus ajax (Sauropoda: Diplodocidae) from the Morrison Formation (Upper Jurassic) of Wyoming, USA. National Science Museum Monographs 26(118):1-156.

Wedel, M. J., Cifelli, R. L., and Sanders, R. K. 2000. Osteology, paleobiology, and relationships of the sauropod dinosaur Sauroposeidon. Acta Palaeontologica Polonica 45(4):343-388.

Whitlock, J. A., D'Emic, M. D., and Wilson, J. A. 2011. Cretaceous diplodocids in Asia? Re-evaluating the phylogenetic affinities of a fragmentary specimen. Palaeontology 54(2):351-364. https://doi.org/10.1111/j.1475-4983.2010.01029.x

Wilson, J. A. 1999. A nomenclature for vertebral laminae in sauropods and other saurischian dinosaurs. Journal of Vertebrate Paleontology 19(4):639-653. https://doi.org/1 $0.1080 / 02724634.1999 .10011178$

Wilson, J.A. 2002. Sauropod dinosaur phylogeny: critique and cladistic analysis. Zoological Journal of the Linnean Society 136(2):217-276. https://doi.org/10.1046/j.10963642.2002.00029.x

Wilson, J. A. 2012. New vertebral laminae and patterns of serial variation in vertebral laminae of sauropod dinosaurs. Contributions from the Museum of Paleontology, The University of Michigan 32(7):91-110.

Wilson, J. A., D'Emic, M. D., Ikejiri, T., Moacdieh, E. M., and Whitlock, J.A. 2011. A nomenclature for vertebral fossae in sauropods and other saurischian dinosaurs. PLoS One 6(2):e17114. https://doi.org/10.1371/journal.pone.0017114

Xing, L., Miyashita, T., Zhang, J., Li, D., Ye, Y., Sekiya, T., Wang, F., and Currie, P. J. 2015. A new sauropod dinosaur from the Late Jurassic of China and the diversity, distribution, and relationships of mamenchisaurids. Journal of Vertebrate Paleontology 35(1):e889701. https://doi.org/10.1080/027 24634.2014.889701

You, H., Li, D., Zhou, L., and Ji, Q. 2006. Huanghetitan liujiaxiaensis, a new sauropod dinosaur from the Lower Cretaceous Hekou Group of Lanzhou Basin, Gansu Province, China. Geological Review 52(5):668-674. 


\section{Appendix 1. Characters scored in the matrix published by González Riga et al. (2018) for the phylogenetic analysis}

VOLGATITAN SIMBIRSKIENSIS GEN. ET SP. NOV.

25(1): Anterior caudal centra, mediolateral width to dorsoventral height (excluding chevron facets) of anterior surface ratio: 1.0 or greater [1.06].

26(1): Anterior caudal centra, lowest average Elongation Index (aEI; centrum anteroposterior length [excluding articular ball] divided by the mean average value of the anterior surface mediolateral width and dorsoventral height) value of: 0.6 or greater [0.79].

27(2): Anterior caudal centra, anteroposterior length of posterior condylar ball to mean average radius ([mediolateral width + dorsoventral height] divided by 4) of anterior articular surface of centrum ratio: greater than 0.3 (posterior articular surface of centrum is strongly convex) [0.63].

28(1): Middle caudal centra, mediolateral width to dorsoventral height (excluding chevron facets) of anterior surface ratio: 1.0 or greater [1.09].

29(0): Middle caudal centra, average Elongation Index (aEI; centrum anteroposterior length [excluding articular ball] divided by the mean average value of the anterior surface mediolateral width and dorsoventral height [excluding chevron facets]) value: less than $1.4[0.94]$.

176(1): Anteriormost caudal vertebrae, camellate internal tissue structure: present.

177(2): Anterior caudal centra, posterior articular surface: convex throughout all anterior caudal vertebrae with ribs.

178(0): Anterior caudal centra, lateral pneumatic fossae or foramina: absent.

180(0): Anterior-middle caudal centra, small, shallow vascular foramina pierce the lateral and/or ventral surfaces: absent.

181(0): Anterior-middle caudal centra (excluding the anteriormost caudal vertebrae), ventral longitudinal hollow: absent.

182(0): Anterior-middle caudal centra (excluding the anteriormost caudal vertebrae), distinct ventrolateral ridges, extending the full length of the centrum: absent.

183(0): Middle caudal centra, anteroposteriorly elongate ridge situated at approximately two-thirds of the way up the lateral surface: absent.

184(1): Middle-posterior caudal centra (at least some), posterior articular surface: convex.

185(1): Middle-posterior caudal centra with convex posterior articular surface: distinct rim rings the condyle, separating it from the lateral surface of the main body of the centrum.
187(1): Anterior caudal neural arches, hyposphenal ridge: absent.

188(1): Anterior caudal neural arches, hyposphenal ridge shape: block-like hyposphene.

189(1): Anterior caudal neural arches, distinct prezygodiapophyseal lamina (PRDL): present.

190(0): Anterior caudal neural arches, sharp lipped lateral coel (postzygapophyseal centrodiapophyseal fossa $[\mathrm{POCDF}]$ ) bounded by posterior centrodiapophyseal lamina (PCDL [or caudal rib itself]), centropostzygapophyseal lamina (CPOL) and postzygodiapophyseal lamina (PODL): absent.

192(1): Middle caudal neural arches: located on the anterior half of the centrum.

202(0): First caudal rib (transverse process), with prominent ventral bulge: absent.

203(0): First caudal rib, expands anteroposteriorly towards its distal end, forming an 'anchor' shape in dorsal view: absent.

204(1): Anterior caudal ribs, shape in anterior view: wing-like, with a dorsolaterally oriented dorsal margin.

205(0): Anterior caudal ribs: curve strongly anterolaterally.

206(0): Anterior caudal ribs: do not extend beyond posterior end of centrum (excluding posterior ball).

349(0): First caudal centrum, anterior articular face shape: flat or concave.

350(0): Anterior-middle caudal centra (excluding Cd1), comparison of anterior and posterior articular faces: anterior face more concave than posterior one, or these two faces are equally concave.

351(0): Middle caudal centra with convex posterior articular surface, condyle dorsally displaced: absent.

352(0): Anteriormost caudal neural arches, prezygapophyses curve downwards ('droop') at their distal ends: absent.

354(0): First caudal rib, subtriangular process projects posteriorly at approximately midlength: absent.

355(0): Anteriormost caudal ribs, tubercle on dorsal surface at approximately midlength: absent.

409(0): Anteriormost caudal centra, ACDL: absent, or represented by no more than a faint ridge.

\section{TENGRISAURUS STARKOVI AVERIANOV ET}

SKUTSCHAS, 2017

25(1): Anterior caudal centra, mediolateral width to dorsoventral height (excluding chevron facets) of anterior surface ratio: 1.0 or greater [1.01].

27(2): Anterior caudal centra, anteroposterior length of posterior condylar ball to mean average radius ([mediolateral width + dorsoventral height] divided by 4) of anterior articular surface of centrum ratio: greater than 0.3 (posterior articular surface of centrum is strongly convex) [0.72]. 
28(1): Middle caudal centra, mediolateral width to dorsoventral height (excluding chevron facets) of anterior surface ratio: 1.0 or greater [1.13].

29(1): Middle caudal centra, average Elongation Index (aEI; centrum anteroposterior length [excluding articular ball] divided by the mean average value of the anterior surface mediolateral width and dorsoventral height [excluding chevron facets]) value: 1.4 or higher [1.43].

33(1): Anterior caudal neural spines, maximum mediolateral width to anteroposterior length ratio: 1.0 or greater [1.93].

34(1): Anterior caudal neural spines, maximum mediolateral width to minimum mediolateral width ratio: 2.0 or greater (spines expand dorsally, forming 'club' - or 'mace'-shaped spinous processes) [2.28]

176(0): Anteriormost caudal vertebrae, camellate internal tissue structure: absent.

177(2): Anterior caudal centra, posterior articular surface: convex throughout all anterior caudal vertebrae with ribs.

178(0): Anterior caudal centra, lateral pneumatic fossae or foramina: absent.

180(0): Anterior-middle caudal centra, small, shallow vascular foramina pierce the lateral and/or ventral surfaces: absent.

181(1): Anterior-middle caudal centra (excluding the anteriormost caudal vertebrae), ventral longitudinal hollow: present.

182(0): Anterior-middle caudal centra (excluding the anteriormost caudal vertebrae), distinct ventrolateral ridges, extending the full length of the centrum: absent.

183(0): Middle caudal centra, anteroposteriorly elongate ridge situated at approximately two-thirds of the way up the lateral surface: absent.

184(1): Middle-posterior caudal centra (at least some), posterior articular surface: convex.

185(1): Middle-posterior caudal centra with convex posterior articular surface: distinct rim rings the condyle, separating it from the lateral surface of the main body of the centrum.

187(0): Anterior caudal neural arches, hyposphenal ridge: present.

188(0): Anterior caudal neural arches, hyposphenal ridge shape: slender ridge.

189(0): Anterior caudal neural arches, distinct prezygodiapophyseal lamina (PRDL): absent.

190(0): Anterior caudal neural arches, sharp lipped lateral coel (postzygapophyseal centrodiapophyseal fossa [POCDF]) bounded by posterior centrodiapophyseal lamina (PCDL [or caudal rib itself]), centropostzygapophyseal lamina (CPOL) and postzygodiapophyseal lamina (PODL): absent.

192(1): Middle caudal neural arches: located on the anterior half of the centrum.
193(1): Middle-posterior caudal neural arches, distance that prezygapophyses extend beyond the anterior margin of the centrum: $20 \%$ or greater of centrum length (excluding ball), elongate prezygapophyses [41\%].

194(0): Anteriormost caudal neural spines, sharp lipped lateral coel (spinodiapophyseal fossa [SDF]) bounded by spinoprezygapophyseal lamina (SPRL), spinopostzygapophyseal lamina (SPOL) and postzygodiapophyseal lamina (PODL): absent.

195(0): Anterior caudal neural spines, project: posterodorsally.

196(0): Anterior caudal neural spines, anterodorsal margin of neural spine: level with or posterior to posterior margin of postzygapophyses.

197(1): Anterior caudal neural spines, prespinal and postspinal laminae: form distinct mediolaterally narrow ridges or laminae along the midline of the prespinal and postspinal fossae.

198(0): Anterior caudal neural spines, spinoprezygapophyseal lamina (SPRL)-spinopostzygapophyseal lamina (SPOL) contact: absent.

199(0): Middle caudal neural spines, in lateral view, widen anteroposteriorly (approximately doubling) from their base to their summit: absent.

200(0): Middle caudal neural spines, extend posteriorly to the mid-point (or beyond) of the proceeding caudal centrum: present (0); absent (usually do not extend beyond the posterior margin of the centrum).

204(0): Anterior caudal ribs, shape in anterior view: triangular, tapering distally.

350(0): Anterior-middle caudal centra (excluding $\mathrm{Cd} 1$ ), comparison of anterior and posterior articular faces: anterior face more concave than posterior one, or these two faces are equally concave.

351(0): Middle caudal centra with convex posterior articular surface, condyle dorsally displaced: absent.

352(0): Anteriormost caudal neural arches, prezygapophyses curve downwards ('droop') at their distal ends: absent.

353(0): Anterior caudal neural spines, anterior expansion of lower portion of spinoprezygapophyseal lamina (SPRL): absent.

409(0): Anteriormost caudal centra, ACDL: absent, or represented by no more than a faint ridge.

410(0): Anterior-middle caudal neural arches: spinopostzygapophyseal lamina (SPOL) shape: SPOL grades smoothly toward postzygapophyses.

411(0): Anterior-middle caudal neural arches, anteroposteriorly oriented ridge and fossa ('shoulder') between prezygapophyses and postzygapophyses: absent.

419(0): Anteriormost caudal neural spines, medial spinoprezygapophyseal laminae (mSPRLs) merge into the prespinal lamina (PRSL) close to the base of the spine: absent. 